NBER WORKING PAPER SERIES

\title{
CAN NON-INTEREST RATE POLICIES STABILIZE HOUSING MARKETS? EVIDENCE FROM A PANEL OF 57 ECONOMIES
}

\author{
Kenneth N. Kuttner \\ Ilhyock Shim \\ Working Paper 19723 \\ http://www.nber.org/papers/w19723
NATIONAL BUREAU OF ECONOMIC RESEARCH
1050 Massachusetts Avenue
Cambridge, MA 02138 \\ December 2013
}

We are grateful for comments by seminar participants at the Bank for International Settlements, Williams College, the RBA-BIS Conference on Property Markets and Financial Stability in Sydney and the Money, Macro and Finance Conference 2013 in London. We thank Claudio Borio, Frank Packer and Peter Pedroni for helpful suggestions and Bilyana Bogdanova, Marjorie Santos, Jimmy Shek and Agne Subelyte for their excellent research assistance. The views presented here are solely those of the authors and do not necessarily represent those of the Bank for International Settlements or the National Bureau of Economic Research.

NBER working papers are circulated for discussion and comment purposes. They have not been peerreviewed or been subject to the review by the NBER Board of Directors that accompanies official NBER publications.

(C) 2013 by Kenneth N. Kuttner and Ilhyock Shim. All rights reserved. Short sections of text, not to exceed two paragraphs, may be quoted without explicit permission provided that full credit, including (C) notice, is given to the source. 
Can Non-Interest Rate Policies Stabilize Housing Markets?

Evidence from a Panel of 57 Economies

Kenneth N. Kuttner and Ilhyock Shim

NBER Working Paper No. 19723

December 2013

JEL No. G21,G28,R31

\begin{abstract}
Using data from 57 countries spanning more than three decades, this paper investigates the effectiveness of nine non-interest rate policy tools, including macroprudential measures, in stabilizing house prices and housing credit. In conventional panel regressions, housing credit growth is significantly affected by changes in the maximum debt-service-to-income (DSTI) ratio, the maximum loan-to-value ratio, limits on exposure to the housing sector and housing-related taxes. But only the DSTI ratio limit has a significant effect on housing credit growth when we use mean group and panel event study methods. Among the policies considered, a change in housing-related taxes is the only policy tool with a discernible impact on house price appreciation.
\end{abstract}

\author{
Kenneth N. Kuttner \\ Department of Economics \\ Williams College \\ Schapiro Hall \\ 24 Hopkins Hall Drive \\ Williamstown, MA 01267 \\ and NBER \\ kenneth.n.kuttner@williams.edu \\ Ilhyock Shim \\ Bank for International Settlements \\ Representative Office for Asia and the Pacific \\ 78th floor, Two IFC, Central, Hong Kong \\ ilhyock.shim@bis.org
}




\section{Introduction}

Following the housing boom and bust of the mid-2000s, the drawbacks of relying on interest rates alone to ensure financial stability have become increasingly clear. As documented elsewhere, the quantitative impact of interest rates on house prices is economically significant but not large enough to achieve a meaningful degree of restraint. ${ }^{1}$ An interest rate hike of sufficient size to meaningfully dampen house price growth would therefore run the risk of causing a recession. As Federal Reserve Chairman Ben Bernanke (2010) put it, monetary policy is a "blunt tool" for stabilizing housing markets. ${ }^{2}$ Moreover, countries with exchange rate targets (either explicit or implicit) lack the freedom to use the interest rate as a policy tool.

The recognition of interest rates' limitations has left policymakers searching for other policy tools to tame housing and other asset markets, either independently or as a complement to interest rate policy. A great deal of attention has been focused on non-interest rate policies, such as reserve requirements and maximum loan-to-value (LTV) ratios, which have been on high and growing demand in many economies. Given the central role of the housing market in the recent crises, it is no surprise that many of these policies are aimed squarely at reining in the housing sector. The critical question is whether these non-interest rate tools really work in modulating house prices and housing credit growth.

This paper is closely related to the rapidly expanding literature on macroprudential policy, whose overarching goal is to limit systemic risk in the financial system as a whole. ${ }^{3}$ The two main objectives of macroprudential policy are, first, to promote the resilience of the financial system by mandating higher levels of liquidity, capital and collateralization; and second, to restrain the buildup of financial imbalances by slowing credit and asset price growth. This paper deals with the second of these two objectives, focusing specifically on imbalances in the housing market. At the same time, it looks at a broad range of policy actions, not just those traditionally associated with macroprudential regulation. These include changes in taxes and subsidies affecting the housing

\footnotetext{
${ }^{1}$ See Kuttner (2014) and the references contained therein.

${ }^{2}$ Partly for this reason, many macroeconomists have argued that the interest rate should not be used to address such developments (e.g. Bernanke \& Gertler (1999), Blanchard et al. (2010), Galí (2013), Ito (2010), Posen (2006) and Svensson (2010)). Others have argued that there is a role for interest rate policy in ensuring financial stability (e.g. Borio (2011), Eichengreen et al. (2011), King (2013), Mishkin (2011), Stein (2013) and Woodford (2012)).

${ }^{3}$ See IMF-BIS-Financial Stability Board (2011) for a more complete discussion of macroprudential policy.
} 
market, and other actions, such as changes in reserve requirements, that are not explicitly justified by macroprudential objectives. We therefore refer to the policies in our paper as credit and housingrelated tax policies, rather than as narrowly-defined macroprudential tools.

A growing body of research has documented the use of tools other than the short-term interest rate in various countries and examined their effectiveness in damping credit growth and house prices. Among the first was Hilbers et al. (2005), who documented that ten of the 18 central and eastern European (CEE) countries responded to house price booms with regulatory policy actions. In the same vein, Crowe et al. (2011) found that out of 36 countries that had experienced real estate booms, 24 had responded with policy measures intended dampen the property market.

Focusing on six countries in Latin America, Tovar et al. (2012) showed that macroprudential policy in general, and reserve requirements in particular, had a moderate but transitory impact on private bank credit growth in the region. More recent work on the CEE economies by Vandenbussche et al. (2012) found that certain types of macroprudential policies, including capital adequacy ratios and non-standard liquidity measures, influenced house price inflation. And taking an international perspective, Borio \& Shim (2007) documented 12 types of macroprudential policy actions taken by 18 European and Asian countries going back as far as 1988. Their event study analysis showed that macroprudential measures reduced credit growth by 4 to 6 percentage points in the years immediately following their introduction, while house prices decelerated in real terms by 3 to 5 percentage points.

Lim et al. (2011) used data from a survey conducted by the International Monetary Fund (IMF) in 2010 to document that 40 of the 49 countries surveyed had taken (broadly defined) macroprudential measures in the preceding 10 years. Using panel regression analysis, they found that a variety of macroprudential tools, including reserve requirements, dynamic provisioning, maximum LTV ratios, maximum debt-service-to-income (DSTI) ratios and limits on foreign currency lending had measurable effects on the growth rate or cyclicality of private sector credit and leverage.

Taking a disaggregated approach, Claessens et al. (2013) analyzed the use of macroprudential policy aimed at reducing vulnerabilities in individual banks in both advanced and emerging market economies, using a sample of about 2,300 banks in 48 countries and macroprudential policy measures documented by Lim et al. (2011). They showed that policy measures such as maximum 
LTV and DSTI ratios and limits on foreign currency lending are effective in reducing leverage, asset and non-core to core liabilities growth during booms, and that few policies help stop declines in bank leverage and assets during downturns.

This paper's goal is to provide a systematic assessment of the efficacy of credit and housingrelated tax policies on housing credit and house prices. The analysis uses a new dataset on the usage of nine of these policy types by 60 countries over a period going as far back as 1980, making it the most comprehensive study to date in terms of both scope and time span. While in some respects similar to Lim et al. (2011), our focus is on housing credit and house prices rather than overall private sector credit. Our study employs three different empirical approaches as a check on the results' robustness. ${ }^{4}$ The main findings are, first, that the maximum DSTI ratio is the policy tool that most consistently affects housing credit growth, with a typical policy tightening slowing housing credit growth by roughly 4 to 7 percentage points over the following four quarters. Second, the evidence suggests that an increase in housing-related taxes can slow the growth of house prices, although this finding is somewhat sensitive to the choice of econometric method.

The plan of the paper is as follows. Section 2 describes each of the nine policies analyzed and sketches a theoretical framework illustrating the channels through which the policies operate. Section 3 describes the data used in the analysis, focusing on the key characteristics of the policy action dataset. Section 4 describes the econometric methods and reports the results. Section 5 concludes.

\section{The operation of credit and housing-related tax policies}

The purpose of this section is, first, to provide some specifics on how these policies operate in practice; and second, to present bare-bones theoretical frameworks to illuminate the conditions necessary for certain types of policies to be effective and the reasons why the effect of policies might vary between countries.

\footnotetext{
${ }^{4}$ This paper builds on Kuttner \& Shim (2012), which explored a similar set of issues. The present paper uses a significantly expanded version of the policy action dataset used in the earlier work and brings additional econometric methods to bear on the analysis.
} 


\subsection{General credit policies}

The three policies in this category are reserve requirements, liquidity requirements and limits on credit growth. All apply to the banking system. Because none of the three is aimed specifically at the housing sector, we refer to them collectively as general credit policies. They might also be characterized as non-interest rate monetary policy tools.

Reserve requirements compel banks to hold at least a fraction of their liabilities as liquid reserves. These are normally held either as reserve deposits at the central bank or as vault cash. The regulation generally specifies the size of required reserves according to the type of deposits (e.g. demand, savings or time deposits), their currency of denomination (domestic or foreign currency) and their maturity.

Liquidity requirements are typically in the form of a minimum ratio of highly liquid assets, such as government securities and central bank paper, to certain types of liabilities. These are prudential regulations whose main objective is to ensure a bank's ability to withstand cash outflows under stress. The main difference between liquidity and reserve requirements is that the former requires the bank to keep funds at the central bank whereas the latter oblige them to hold liquid marketable securities. The two policies are very similar in terms of their economic effect, as both influence the volume of funds available for lending to the private sector by imposing constraints on the composition of banks' balance sheets.

Finally, limits on the expansion of private sector credit are sometimes imposed during lending booms. This may take the form of a numerical ceiling on the rate of credit growth per month or year, or a maximum amount of the increase in lending per month or per quarter. Another aspect of those policies is a set of penalties on violating the specified limit.

\section{A deposit-dependent bank}

The starting point for modelling banks' loan supply is the profit-maximizing choice of balance sheet composition. Profits for a bank whose sole source of funds consists of reservable demand deposits would be

$$
\Pi=r_{L} \cdot L+r_{R} \cdot R-r_{D} \cdot D
$$


where $L, R$ and $D$ are loans, reserves and demand deposits, and $r_{L}, r_{R}$ and $r_{D}$ are the corresponding interest rates. $^{5}$

If banks hold some fixed regulatory mandated share $\psi$ of deposits as reserves, the expression for profits can be written as

$$
\Pi=[r_{L}-r_{D}-\underbrace{\psi\left(r_{L}-r_{R}\right)}_{\text {reserve tax }}] D .
$$

And since $L=(1-\psi) D$, profits can be also expressed as a function of $L$,

$$
\Pi=\left[r_{L}-r_{D}-\psi\left(r_{L}-r_{R}\right)\right](1-\psi)^{-1} L
$$

For simplicity, we assume that the reserve requirement constraint holds with equality. ${ }^{6}$

If interest rates were exogenous, then the supply of loans would be perfectly elastic: for $\Pi>0$ the bank would supply an infinite amount of funds, and zero if $\Pi<0$. The supply curve would be a horizontal line at $r_{L}=(1-\psi)^{-1}\left(r_{D}-\psi r_{R}\right)$. An increase in $\psi$ shifts the supply curve up, as would a decrease in $r_{R}$.

Equilibrium requires either that $r_{D}$ is an increasing function of $D$, or that $r_{L}$ is a decreasing function of $L$. One way to determine the equilibrium is to have a downward-sloping loan demand curve. In this model, households demand a greater amount of housing loans to support more consumption of housing services only when the loan rate $r_{L}$ decreases. This can be rationalized in a utility-maximizing model with declining marginal utility in the consumption of housing services. Note that there is nothing "special" about banks in this model. Reserve requirements affect equilibrium $L$ only if one assumes that banks are the only source of finance, or that at least some subset of households are bank-dependent.

Another way to obtain a downward-sloping loan demand curve is to assume that the agency costs associated with lending are a function of leverage, and hence $L$. Increases in the interest rate $r_{L}$ have the effect described above, but by decreasing the value of collateral, they also increase

\footnotetext{
${ }^{5}$ The model omits capital for simplicity's sake.

${ }^{6}$ Banking systems differ greatly across countries in the degree to which reserve requirements are binding. As of April 2012, the Korean banking system held virtually no excess reserves, while that of the Philippines held only 4.6 billion pesos ( $\$ 100$ million). Until the quantitative easing policies that began in 2008, the US banking system held only a trivial amount of excess reserves. In contrast, the figure for Thailand is 2 trillion baht ( $\$ 45$ billion), the equivalent to almost one fifth of GDP.
} 
information costs. This drives a wedge between the lending rate and the cost of funds, the essence of the broad credit channel or "financial accelerator." If so, then the increase in agency costs brought on by an increase in $r_{L}$ reduces lending to affected households. Of course, for this to have an aggregate effect requires that the unconstrained households do not just step in and fill the gap in housing purchases left by the reduction in spending by the constrained households.

A third way to obtain an equilibrium is to assume that $r_{D}$ is an upward-sloping function of $D$. One way is to relax the assumption that the reserve requirement is always binding. It would be possible, for example, to assume a loss function that penalizes deviations from target level of reserves. Lending reduces the desired level of reserves, which is costly. Also, attracting deposits requires getting households to save more, which requires a higher $r_{D}$.

To summarize, in this framework changes in reserve requirements will affect housing credit only if:

1. Some subset of households is bank-dependent for whatever reason (by flatly assuming it or by motivating it in a model with agency costs).

2. The reduction in credit demand coming from constrained borrowers is not offset by borrowing by unconstrained borrowers. This would be true if the marginal product of firms' investment projects were declining (as in the neoclassical model) or if unconstrained borrowers had a downward-sloping demand for housing (this ties into the model of household utility maximization).

3. Some share of any change in total bank lending is manifested in changes in housing credit.

\section{A bank with non-reservable funding sources}

The banking model sketched above is unrealistic to the extent that banks rely on non-reservable funding sources that allow them to increase lending without being constrained by reserve requirements. This is highly relevant to the United States, where total bank reserves fell from $\$ 30$ billion in 1994 to $\$ 10$ billion in 2006, even as commercial bank credit grew from $\$ 3$ trillion to $\$ 7$ trillion. The same issue would arise if lending were securitized and removed from banks' balance sheets, as was the bulk of housing credit in the United States during the boom.

The banking model can be made more realistic by allowing banks to raise funds through reserv- 
able demand deposits, $D D$, and non-reservable certificates of deposit, $C D$. Profits are now given by

$$
\Pi=r_{L} \cdot L+r_{R} \cdot R-r_{D D} \cdot D D-r_{C D} \cdot C D
$$

Since $L=(1-\psi) D D+C D$, profits can be also expressed as a function of $L$ and $D D$,

$$
\Pi=\left(r_{L}-r_{C D}\right) L+\left(r_{C D}-r_{D D}\right) D D-\psi\left(r_{C D}-r_{R}\right) D D
$$

For simplicity, assume that $D D$ is fixed and that $C D$ is the marginal source of funding. The loan supply curve would then be a horizontal line at $r_{L}=r_{C D}$. As in the case without non-reservable funding, one way to obtain an equilibrium in the loan market is to assume downward-sloping loan demand curve.

Another way to obtain an equilibrium is to assume an upward-sloping supply of non-reservable $C D$ s, which would translate into an upward-sloping loan supply curve. This assumption also makes it possible for reserve requirements to affect loan supply. An increase in $\psi$ would reduce the supply of funds coming from $D D$, and given $L$, this would require an increase in $C D$. If the supply of $C D$ s is upward-sloping (perhaps because it increases the agency costs associated with banks' borrowing), then this would raise banks' cost of funds and shift the loan supply curve upward.

To summarize, if banks can obtain non-reservable funding, then in addition to the three conditions enumerated previously, we have to assume that

4. The supply curve for non-reservable funding is upward-sloping.

\subsection{Targeted credit policies}

A second category of credit policies encompasses those intended specifically to limit the growth of housing credit. These include the imposition of a maximum LTV or DSTI ratio, both of which affect households' demand for housing credit. Supply-side tools are also used to restrain the volume of housing credit supplied by the banking system. These include the imposition of limits on exposure to the housing sector, the adjustment of risk weights applied to housing loans and changes in provisioning requirements. Since these five types of measures are also intended to limit banks' and households' exposure to risk, they might also be referred to as prudential policy tools. 


\subsubsection{Demand-side policy instruments}

In order to slow housing loan growth and build up buffers within banks against potential losses from housing loans, national authorities often either impose a maximum LTV ratio applied to home mortgages or lower the pre-existing maximum. The authorities may also prohibit certain types of housing loans, which is equivalent to applying a zero LTV ratio. For example, when housing markets were overheating in 2012, the Chinese authorities prohibited banks from making loans to purchase second or third houses and also barred foreigners and non-residents from borrowing from banks to purchase houses.

Another frequently used way of restricting the excessive provision of housing credit is to limit the DSTI ratio (or debt service ratio) applied to the borrowing of home buyers. Typically, regulators specify a certain percentage of the borrower's monthly income as the maximum monthly repayment on a bank loan. Less frequently, limits to the loan amount can be expressed as a multiple of household income (i.e. maximum debt-to-income ratio) or regulators can limit the minimum debt-repayment-to-debt ratio. Alternatively, authorities can lengthen the maximum maturity of mortgage contracts or introduce preferential interest rates for mortgage loans, thus easing the repayment burden for mortgage borrowers. All such measures are classified as "other lending criteria."

A simple two-period utility maximizing model can be used to shed light on the impact of demand-side credit instruments. Households choose between consumption today, consumption tomorrow, and the quantity of housing:

$$
\max _{c_{1}, c_{2}, h} u\left(c_{1}\right)+\frac{1}{1+\rho} u\left(c_{2}\right)+v(h)
$$

such that

$$
c_{1}+p_{1} h+\frac{1}{1+r} c_{2} \leq \frac{p_{2} h}{1+r}+y_{1}+\frac{1}{1+r} y_{2} .
$$

In the context of an overlapping generations model, period 1 would represent the early part of the life cycle in which households purchase a home (for a price $p_{1}$ ), and period 2 represents retirement in which households draw down housing equity in order to finance consumption (i.e. they sell the house for a price $\left.p_{2}\right)$. 
The two first-order conditions are the usual consumption Euler equation,

$$
u^{\prime}\left(c_{1}\right)=\frac{1+r}{1+\rho} u^{\prime}\left(c_{2}\right)
$$

and

$$
u^{\prime}\left(c_{1}\right)=\left[p_{1} \frac{r-\pi}{1+r}\right]^{-1} v^{\prime}(h)
$$

The term in square brackets is the user cost of home ownership and $\pi$ is the expected rate of house price appreciation. $^{7}$

Alternatively, the household could pay rent $R$ to obtain housing services in periods 1 and 2 , in which case the first-order condition would be

$$
u^{\prime}\left(c_{1}\right)=R^{-1} v^{\prime}(h)
$$

Equations 9 and 10 together imply that if households are unconstrained, then in equilibrium, rent and user cost will be equal.

Combining the first-order conditions with the budget constraint will yield a downward-sloping demand for $h$ as a function of $\pi, r, p_{1}$ and permanent income. Note that borrowing in the first period is equal to $c_{1}+p_{1} h-y_{1}$.

A limit on the DSTI ratio imposes the following condition on the budget constraint:

$$
\text { credit }=c_{1}+p_{1} h-y_{1} \leq \phi y_{1} / r
$$

At the risk of stating the obvious, the DSTI constraint becomes less likely to bind as the interest rate declines.

Analogously, a limit on the LTV ratio looks like:

$$
\text { credit }=c_{1}+p_{1} h-y_{1} \leq \theta p_{1} h
$$

\footnotetext{
${ }^{7}$ Physical depreciation is ignored in order to keep things simple. Taxes, which also affect the user cost, are discussed below.
} 
Again noting the obvious, the existence of a maximum LTV ratio allows housing credit to rise along with the house price or forces housing credit to fall along with the house price. This suggests that a reduction in the maximum LTV ratio (tightening) is likely to be less effective than a reduction in the maximum DSTI ratio (tightening) when it comes to restraining credit growth during house price booms.

For example, suppose that the actual LTV ratio equals the maximum LTV ratio of $80 \%$. When the value of a house increases by $15 \%$ this year, under the current maximum LTV ratio households can borrow $15 \%$ more. Therefore, even after the maximum LTV ratio is lowered by 10 percentage points from $80 \%$ to $70 \%$ this year, the credit growth over the year is positive. By contrast, household income does not typically grow over a year as fast as house prices, so there is more room for tightening the maximum DSTI ratio to be effective than for tightening the LTV ratio by the same amount. Likewise, an increase in the maximum LTV ratio (loosening) seems to be less effective than an increase in the maximum DSTI ratio (loosening) when it comes to promoting credit growth during house price downturns. In particular, when the house price falls, to meet the current maximum LTV ratio the loan amount also needs to fall. Thus, an increase in the maximum LTV ratio may not be enough to avoid a net decrease in credit. Moreover, the interaction of house prices and housing credit over time (especially during credit-fuelled housing booms) tends to further limit the effect of adjusting the maximum LTV ratio.

The utility function can be maximized subject to the budget constraint plus either the LTV or the DSTI constraint (equation 11 or 12). The first-order condition in the case of a hard borrowing constraint case $(\theta=0)$,

$$
u^{\prime}\left(y_{1}-p_{1} h\right)=\frac{1}{p_{1}} v^{\prime}(h)+\frac{1+\pi}{1+\rho} u^{\prime}\left(p_{2} h+y_{2}\right)
$$

implicitly defines a downward-sloping demand curve for $h$ as a function of $\pi, r, p_{1}$ and permanent income. Note that this is very similar to the consumption Euler equation: housing earns a rate of return $\pi$ and functions as a vehicle for saving, but the $v^{\prime}$ term says that the household also receives utility from the house it owns. 
The demand curve under the DSTI constraint is given by the analogous first-order condition,

$$
u^{\prime}\left(\left(1+r^{-1} \phi\right) y_{1}-p_{1} h\right)=\frac{1}{p_{1}} v^{\prime}(h)+\frac{1+\pi}{1+\rho} u^{\prime}\left(p_{2} h+y_{2}\right)
$$

An increase in the binding maximum DSTI ratio, $\phi$, means that for a given $h$, the household will be able to borrow more for first-period consumption. This reduces $u^{\prime}\left(c_{1}\right)$, and the household will respond by increasing $h$. Note also that an increase in $p_{1}$ causes a one-for-one reduction in the resources available for first-period consumption.

The optimal allocations for different levels of the maximum DSTI ratio may be summarized as follows:

- When the maximum DSTI ratio, $\phi$, is not binding (the unconstrained case),

$$
\text { credit }=p_{1} h^{*}-\left(y_{1}-c_{1}^{*}\right) \geq 0 \text { and debt repayment }=r\left(c_{1}^{*}+p_{1} h^{*}-y_{1}\right)<\phi y_{1} .
$$

- When the maximum DSTI ratio, $\phi^{\prime}$, is binding (the constrained case),

$$
\text { credit }=p_{1} h^{\prime}-\left(y_{1}-c_{1}^{\prime}\right) \geq 0 \text { and debt repayment }=r\left(c_{1}^{\prime}+p_{1} h^{\prime}-y_{1}\right)=\phi^{\prime} y_{1}
$$

- When the maximum DSTI ratio, $\tilde{\phi}$, is binding and $\tilde{\phi}>\phi^{\prime}$,

$$
\text { credit }=p_{1} \tilde{h}-\left(y_{1}-\tilde{c}_{1}\right) \geq 0 \text { and debt repayment }=r\left(\tilde{c}_{1}+p_{1} \tilde{h}-y_{1}\right)=\tilde{\phi} y_{1}
$$

- From equations 16 and 17 ,

$$
\tilde{c}_{1}+p_{1} \tilde{h}=(1+\tilde{\phi} / r) y_{1} \text { and } c_{1}^{\prime}+p_{1} h^{\prime}=\left(1+\phi^{\prime} / r\right) y_{1}
$$

Since $(1+\tilde{\phi} / r) y_{1}>\left(1+\phi^{\prime} / r\right) y_{1}, \tilde{c}_{1}+p_{1} \tilde{h}>c_{1}^{\prime}+p_{1} h^{\prime}$. Therefore, if $\tilde{c}_{1}=c_{1}^{\prime}, \tilde{h}>h^{\prime}$ and if $\tilde{h}=h^{\prime}, \tilde{c}_{1}>c_{1}^{\prime}$. This means that when the DSTI constraint is binding and the authorities lower the maximum DSTI ratio, households respond either by lowering their housing demand or by lowering their first-period consumption.

With a binding maximum LTV requirement with $0<\theta<1$, housing demand is given by

$$
(1-\theta) u^{\prime}\left(y_{1}-(1-\theta) p_{1} h\right)=\frac{1}{p_{1}} v^{\prime}(h)+\frac{1+\pi}{1+\rho} u^{\prime}\left(p_{2} h+y_{2}\right) .
$$


A key difference between this and the DSTI-constrained demand relationship is the $1-\theta$ factor multiplying $u^{\prime}\left(c_{1}\right)$ on the left-hand side of the equation. The factor reflects the fact that when the maximum LTV ratio is binding, because a fraction of the cost of purchase is borrowed, a one-unit increase in $h$ causes a less than one-for-one reduction in the resources available for firstperiod consumption. An increase in the binding maximum LTV ratio, $\theta$ (loosening the constraint), therefore, has both an inframarginal effect (increasing $c_{1}$ for a given $h$ ) and a marginal effect (raising the marginal opportunity cost in terms of $c_{1}$ ) of an increase in $h$. But unlike in the case of the DSTI constraint, an increase in $p_{1}$ has a less than one-for-one effect on the feasible $c_{1}$.

The optimal allocations for different levels of the maximum LTV ratio may be summarized as follows:

- When the maximum LTV ratio, $\theta$, is not binding (the unconstrained case),

$$
\text { credit }=p_{1} h^{*}-\left(y_{1}-c_{1}^{*}\right) \geq 0 \text { and }\left(c_{1}^{*}+p_{1} h^{*}-y_{1}\right)<\theta p_{1} h^{*} .
$$

- When the maximum LTV ratio, $\theta^{\prime}$, is binding (the constrained case),

$$
\text { credit }=p_{1} h^{\prime}-\left(y_{1}-c_{1}^{\prime}\right) \geq 0 \text { and }\left(c_{1}^{\prime}+p_{1} h^{\prime}-y_{1}\right)=\theta p_{1} h^{\prime}
$$

- When the maximum LTV ratio, $\tilde{\theta}$, is binding and $\tilde{\theta}>\theta^{\prime}$,

$$
\text { credit }=p_{1} \tilde{h}-\left(y_{1}-\tilde{c_{1}}\right) \geq 0 \text { and }\left(\tilde{c_{1}}+p_{1} \tilde{h}-y_{1}\right)=\tilde{\theta} p_{1} \tilde{h}
$$

- From equations 21 and 22,

$$
\frac{1}{\tilde{h}}\left(y_{1}-\tilde{c}_{1}\right)=(1-\tilde{\theta}) p_{1} \text { and } \frac{1}{h^{\prime}}\left(y_{1}-c_{1}^{\prime}\right)=\left(1-\theta^{\prime}\right) p_{1} .
$$

Since $\left(1-\theta^{\prime}\right) p_{1}>(1-\tilde{\theta}) p_{1}, 1 / h^{\prime}\left(y_{1}-c_{1}^{\prime}\right)>1 / \tilde{h}\left(y_{1}-\tilde{c}_{1}\right)$. Therefore, if $\tilde{c}_{1}=c_{1}^{\prime}$, then $\tilde{h}>h^{\prime}$ and if $\tilde{h}=h^{\prime}$, then $\tilde{c_{1}}>c_{1}^{\prime}$. This means that when the LTV constraint is binding and the authorities lowers the maximum LTV ratio, the households respond either by lowering their housing demand or by lowering their first-period consumption.

This is little more than a sketch of the demand for housing credit. It nonetheless suffices to highlight the ways in which the imposition of maximum LTV and DSTI ratios will affect credit demand. Both shift the demand curve inward, although there are subtle differences having to do with the ways in which house price appreciation and the interest rate affect the respective con- 
straints. The overall effect on housing demand will, of course, depend on the share of households

that are liquidity-constrained. Deriving the implications for house prices would require the supply side of the model to be fleshed out, but clearly the impact will depend not only on the share of credit-constrained households, but also on the slope of unconstrained households' demand curve for housing. If demand is highly elastic, then a drop in constrained households' demand for housing (credit) will be offset by an increase in the housing consumed by unconstrained households. Importantly, the existence of credit-constrained households is not a necessary condition for taxes to affect the house price, as these directly affect the user cost of home ownership.

\subsubsection{Supply-side policy instruments}

The three policy tools aimed at housing credit supply are provisioning requirements, risk-weighting, and exposure limits. The first two are similar to reserve and liquidity requirements in the sense that they affect bank loan supply through the cost of funds. The difference is that they apply specifically to housing credit, and consequently we classify them as targeted credit policies. By contrast, exposure limits affect the housing credit supply, not through the cost of funds but through the quantitative limit on banks' supply of housing loans.

By limiting the exposure of banks toward the housing or property sector as a percentage of the total assets or liabilities, this type of measure aims to slow down rapid expansion of housing loans by banks (and also limit the losses from housing loans when the housing prices correct and housing loan defaults surge). A limit on housing loan exposure is sometimes set as a certain percentage of a bank's equity.

Under Basels I, II or III, housing loans are subject to different risk weights than corporate or sovereign exposures. Raising risk weights on housing loans makes it more costly for banks to extend housing loans given a fixed amount of bank equity. Often, risk weights are differentiated by the actual LTV ratio of individual loans. For example, the parts of a housing loan's LTV ratio that are higher than a certain threshold (say, 80\%) may carry a higher risk weight. Similar to risk weights, increases (or reductions) in general loan loss provisions and specific loan loss provisions applied to housing loans can be used to make housing loans more (or less) costly and thus help slow (or spur) growth in housing credit. 


\subsection{Housing-related tax policies}

The final category of policies considered consists of measures that affect the cost of purchasing a home. They include taxes (such as capital gains, wealth and value added taxes), subsidies (on firsttime home buyers and young couples and also on mortgage interest payment), fees (such as stamp duties and registration fees) and tax deductibility of mortgage interest payments. For brevity, all are referred to as housing-related taxes.

The effects of these taxes are easy to understand in the context of the user cost (UC) framework. Note that the effects on the house price does not depend on the existence of credit-constrained households. A tax increase would increase the UC even if everyone could be unconstrained. The effects on credit depend on the elasticity of housing demand. If demand were perfectly inelastic, the quantity of housing purchased would remain unchanged, as would housing credit.

\section{Data}

The analysis in Section 4 spans the period from 1980Q1 to 2011Q4 and covers 57 advanced and emerging market economies. ${ }^{8}$ These include 13 economies from the Asia-Pacific region (Australia, China, Hong Kong SAR, India, Indonesia, Japan, Korea, Malaysia, New Zealand, the Philippines, Singapore, Thailand and Chinese Taipei), 15 from central and eastern Europe (Bulgaria, Croatia, the Czech Republic, Estonia, Hungary, Latvia, Lithuania, Poland, Romania, Russia, Serbia, Slovakia, Slovenia, Turkey and Ukraine), six from Latin America (Argentina, Brazil, Chile, Colombia, Mexico and Peru), two from the Middle East and Africa (Israel and South Africa), two from North America (Canada and the United States) and 19 from western Europe (Austria, Belgium, Denmark, Finland, France, Germany, Greece, Iceland, Ireland, Italy, Luxembourg, Malta, the Netherlands, Norway, Portugal, Spain, Sweden, Switzerland and the United Kingdom). This section summarizes the data sources and the criteria used for selecting the economies and subsamples, and reports descriptive statistics for the key variables used in the analysis.

\footnotetext{
${ }^{8}$ As discussed in Section 3.3, data limitations require the United Arab Emirates, Saudi Arabia and Uruguay to be excluded from the analysis.
} 


\subsection{The policy action dataset}

The heart of the empirical analysis and a major contribution of the paper is a new, comprehensive dataset of non-interest rate policies affecting housing credit and house prices. The dataset includes 60 economies, spanning a period going back to January 1980 for some economies and running through June 2012. The database is a superset of the one described in Shim et al. (2013), which covers a shorter period (starting in 1990) and excludes changes in housing-related tax policy. Appendix Table 1 provides details on the dates of coverage of the policy database.

The policy action dataset draws on a variety of sources. Wherever possible, we use official documents from central banks, regulatory authorities and ministries of finance of 60 economies, including their annual reports, financial stability reports, monetary policy bulletins, supervisory authorities' circulars, budget reports, ministry of finance announcements on tax changes and press releases from these institutions. We also consulted Borio \& Shim (2007), a survey by the Committee on the Global Financial System (CGFS) on macroprudential policy conducted in December 2009, Hilbers et al. (2005), Crowe et al. (2011), Lim et al. (2011), and Tovar et al. (2012). Where these secondary sources were used, we cross-checked the information from the secondary sources against the information obtained from official documents. We then used our database of policy actions to generate variables capturing the tightening and loosening of the policy instruments.

There are clear pros and cons to this approach. One benefit is that the dataset should in principle provide a complete list of all relevant policy actions officially published by central banks and financial authorities, while an ad hoc survey could suffer from incomplete identification of relevant policy actions. Moreover, by reading through official publications, we can obtain full and accurate information on each of the potentially relevant policy actions. These details allow us to use uniform criteria when determining which measures to include and how to record them consistently. ${ }^{9}$ Another benefit of relying on official publications is accurate identification of the implementation date of each policy action. One disadvantage of using official sources is the language barrier for some countries, given that English translations for such documents may be unavailable for earlier periods. Also, for a limited number of countries, archives available on the websites of relevant au-

\footnotetext{
${ }^{9}$ The IMF survey described in Lim et al. (2011) includes only those actions taken for explicitly macroprudential purposes, and therefore excludes a large number of policy changes that are likely to have affected the housing market.
} 
thorities or offline publication archives available from the BIS library may have one or two missing years. Therefore, we may have omitted relevant policy actions taken in these missing years.

The policy changes are categorized along the lines laid out in Section 2. The first category encompasses general credit policy measures: minimum reserve requirements, liquidity requirements and limits on credit growth. The latter two policy actions are relatively infrequent, however, and so in the empirical work performed below, the three are aggregated into a single variable representing this class of policy.

The database includes changes in various forms of reserve requirements. In particular, we consider changes in the reserve requirement ratio and reserve base. We do not consider changes in the remuneration rates, reserve maintenance periods or averaging methods because we focus on policy actions directly targeting the aggregate quantity of funds available for lending. However, it should be noted that this distinction is not clear-cut to the extent that reserve requirements also operate, in effect, by influencing the cost of lending. We also include both average reserve requirements, where a certain reserve requirement ratio applies to all outstanding amount of eligible liabilities, and marginal reserve requirements, with which additional liabilities banks assume after certain dates or the amount of liabilities exceeding the level of banks' liabilities as of certain dates are subject to often very high reserve requirement ratios.

The second category consists of the targeted credit policy measures: maximum LTV ratios, maximum DSTI ratios, risk weights on housing loans, provisioning requirements (general loanloss provisioning ratios and specific provisioning ratios applied to housing loans) and exposure limits on banks to the housing sector. Finally, the third category includes housing-related tax policy measures: taxes (such as capital gains tax, wealth tax and value added tax related to housing), subsidies (on first-time home buyers and young couples and also on mortgage interest payment), fees (such as stamp duties and registration fees) and tax deductibility of mortgage interest payments. We only include in the database only nationwide measures targeting middle-income or high-income groups who are potential homebuyers. Thus, tax measures applied to one or two cities or subsidies given specifically to low-income families are not included.

Heterogeneity is intrinsic to the policy action dataset. Even with the application of uniform selection criteria across countries, the specifics of policy actions differ across countries and over 
time. For example, the dataset includes the introduction of a maximum LTV ratio as well as the subsequent reductions and increases in the ratio. Also, in some economies total household income is used in calculating the DSTI, while in others the borrower's income is used. Including these data in a regression model therefore requires some degree of standardization and aggregation. Our solution is to create monthly variables that take on three discrete values: 1 for tightening actions, -1 for loosening actions and 0 for no change. ${ }^{10}$ The monthly observations are summed to create quarterly time series. This means that if multiple actions in the same direction were taken within a given quarter, the variable could take on the values of 2 or -2 , or even 3 and -3 . It also means that a tightening action and a loosening action taken within the same quarter would cancel each other out. Changes in reserve requirements account for nearly all closely spaced actions. With only a few exceptions, no more than one of the other types of policy actions is observed in any given quarter.

Table 1 tabulates the different types of policy actions, aggregated by region. The dataset contains a total of 1,111 policy actions in all, of which roughly 55\% (607) are tightening, and $45 \%$ (504) are loosening. The table shows that the most active users of credit policies are the Asia-Pacific and CEE economies in terms of both the absolute number of actions recorded in the database and the average number of actions per region per decade. The Asia-Pacific economies and western European countries are the most frequent users of housing-related tax measures. It is also clear that reserve requirements are by far the most frequently used of the nine categories of policy, accounting for roughly half of all the actions. Liquidity requirements and credit growth restrictions are relatively less frequently used. Among the targeted credit policies, LTV restrictions are most popular, followed by risk weights, DSTI restrictions, provisioning and exposure limits.

Figure 1 shows that the use of these policies varies a great deal between countries. A large share of the countries in the sample used credit and housing-related policies only occasionally. Several countries were very active users of these policies, with 20 or more documented policy actions per decade. About $30 \%$ of the total number of policy changes in the dataset were taken by these very active users.

Since the dataset documents policy actions implemented by each economy every month from

\footnotetext{
${ }^{10}$ Some of the policy measures that are more standard across countries, such as reserve requirements, would be more amenable to a numerical representation.
} 
January 1980, we can show which types of measures were actively used over the past three decades or so. Figure 2 shows how often each of the nine types of policy action was used over the period from 1980 to 2012 . We find that the total number of policy actions has increased steadily from the 1980s, to 1990s, 2000s and between January 2010 and June 2012. This is also the case for the total number of policy actions per country per decade. ${ }^{11}$

The mix of policies has also varied over time. In the 1980s, more than $90 \%$ of policy actions documented in the dataset were general credit policy measures, dominated by changes in reserve requirements. In the 1990 s, the share of general credit policy actions fell to $76 \%$, while the share of targeted credit policy measures increased from zero to 13\%. The share of targeted credit policy measures continued to rise in the 2000 s, when it more than doubled to $28 \%$, while that of general credit policy measures decreased to 57\%. Finally, over the two and a half years between January 2010 and June 2012, the share of general credit policy actions further declined to $51 \%$, and at the same time that of targeted credit policy measures increased by the same amount to $33 \%$ led by the active use of LTV measures. It should be noted that, in contrast to the shares of general and targeted credit policy measures that have changed substantially over the three decades or so, the share of housing-related tax measures has remained stable between $10 \%$ and $15 \%$ over the same period.

Table 2 shows the correlations between the various policy measures. Panel A displays the correlation matrix for the discrete policy change variables. Most of these correlations are relatively small, indicating that there is little tendency for a country to take different kinds of policy action within the quarter. The one exception is the 0.37 correlation between DSTI and LTV actions, suggesting that the two policies are often used in conjunction. Panel B displays the correlations between cumulative policy indicators, constructed by summing current and previous quarters' policy changes. This takes into account the possibility of co-movements between the policies that may not occur within the same quarter. The relationship between the DSTI and LTV variables is even stronger in this case, with a correlation of 0.58 . There is also some evidence that changes in provisioning requirements accompany changes in the DSTI and LTV requirements.

To give a sense of how these policies have been implemented in practice, Figures 3 to 5 dis-

\footnotetext{
${ }^{11}$ See Shim et al. (2013) for more a more detailed description of policy usage.
} 
play selected cumulative policy indicators along with the short-term nominal interest rate for three Asian economies that have been active users of the policies. The figures show that the deployment of these policies varies greatly from country to country. They have been used to complement conventional interest rate policy in some episodes, while in others they have functioned as substitutes. Similarly, the various credit and housing-related tax policy measures have sometimes been used in concert, and independently at other times.

In China (Figure 3), for example, the short-term interest rate, reserve requirements, LTV and DSTI requirements have all tended to move in the same direction: tightening in 2006-08, loosening in 2008-09, and tightening from 2010. The relationship between the LTV and DSTI measures is particularly close. Since 2002, there has been a steady trend towards more restrictive policy in all three non-interest rate dimensions.

In Hong Kong SAR (Figure 4), the tightening of credit growth limits was the only monetary tool used in 1993. Targeted credit measures (mostly changes in the maximum LTV ratio) were used actively from the mid-1990s, usually in parallel with the general direction of interest rates in Hong Kong SAR (as well as those in the United States). The opposite has been true since 2009, when the LTV requirements have been progressively tightened even as the short-term interest rate has fallen (tracking the US rate). Hong Kong authorities have also made more active use of tax measures since 2009 .

In Korea (Figure 5), reserve requirements were the primary non-interest rate policy tool used throughout the 1990s, rising along with the short-term interest rate (except during the Asian financial crisis). Since 2002, the short-term interest rate has remained stable, but the maximum DSTI and LTV ratios have been tightened considerably. Both ratios followed a similar upward trajectory, although the tightening in the LTV requirements started roughly three years prior to the tightening of the DSTI requirements. As in China, the LTV and DSTI requirements are both significantly more restrictive now than they were 10 years ago.

\subsection{Housing credit, house price and macroeconomic data}

Another contribution of the paper is its use of an extensive new dataset of house prices. The starting point is the BIS property price database. ${ }^{12}$ We enlarged this dataset using data from statistics from

\footnotetext{
${ }^{12}$ Available at http://www.bis.org/statistics/pp.htm.
} 
official sources and, in a few instances, from proprietary private sector sources such as CEIC. When multiple housing price indices are available for a given economy, for example nationwide versus major city indices, we use indices for major cities, as these are the areas that would be most susceptible to overvaluation and are often addressed by targeted credit policy and housing-related tax policy. Data are available for 57 economies, although the time series are quite short in many cases. Brazil's data only go back to 2010Q4, for example. Appendix Table 2 lists the starting and ending dates for the house price series.

The property price data are highly imperfect. The definition of housing price indices varies across the economies. The methods used in the construction of the price indices (e.g. quality adjustment) vary greatly between economies, as does the definition of the relevant housing market (e.g. flats versus detached houses). Moreover, in some cases two or more series must be spliced together in order to yield a usable time series. In India, for example, we combined the Mumbai housing price series provided by the Reserve Bank of India, which ends in 2010Q2, with a new price index from the National Housing Bank, which is available from 2010Q3. Conclusions involving the level of property prices are therefore problematic, especially cross-country comparisons. Recognizing these limitations, we will proceed on the assumption that these series can serve as informative indicators of cyclical swings in the residential property market, if not the price levels.

Household credit data were compiled from a similarly diverse set of sources. The primary source is the BIS data bank, supplemented with series from Datastream, CEIC and central bank websites. Data are available for 57 countries, although for several economies the series only begin in the late 2000s. And as with the price data, the sources and definitions are not always consistent, even within a country. The starting and ending dates for the housing credit series are also listed in Appendix Table 2.

The empirical work also uses a number of macroeconomic time series. One is the consumer price index, obtained from the IMF's International Financial Statistics database. The IMF is also the source for most of the short-term interest rate series, supplemented in several cases with data from national sources or Haver Analytics.

Ideally, our analysis would also include a measure of personal disposable income. These data are difficult or impossible to obtain for the majority of countries we are looking at, however. We 
therefore used as a proxy annual real per capita gross national income (GNI) from World Bank's World Development Indicators database, interpolated to a quarterly frequency.

\subsection{Sample selection criteria}

Data availability is the main constraint on the scope of our analysis. As previously noted, the United Arab Emirates lacks interest rate data while Uruguay and Saudi Arabia have no house price or housing credit data, narrowing our sample to 57 economies. For most countries, the 2011Q4 endpoint is constrained by the GNI data, which were only available through that date at the time of writing.

For some countries, data are available, but the time series are too short to be of any use. Economies with fewer than 16 usable quarterly observations (accounting for the loss of observations from lags and differencing) are excluded. This criterion eliminates Brazil from the house price regression. Similarly, Iceland and Serbia are dropped from the regressions involving housing credit.

Even where data are available, there are often good reasons to discard a portion of the sample. We exclude periods of extreme macroeconomic instability, as these are accompanied by extremely high inflation and interest rates. Argentina's 1990 and 2002 crises are prime examples of such episodes. In order to prevent these anomalous observations from unduly influencing the results, we postpone the regression start dates to avoid these periods.

Poor data quality is another reason for truncating the sample. While there is no good way to independently verify the reliability of the data, many of the series exhibit extreme volatility during the first few quarters for which they are available. Some of the observed spikes may be the result of very rapid growth from a small base, or an artifact of small samples or thin markets. This is a common issue among the CEE economies. The regression starting date is delayed in these cases in order to exclude these periods. Large changes that appear to genuinely reflect conditions in the housing market are not dropped.

Table 3 reports descriptive statistics for the housing credit, house price and macroeconomic data, after the sample selection criteria are applied. Even with the elimination of the most extreme

observations, there is still a great deal of volatility in the data, especially in house prices and housing credit. The standard deviations of the annualized quarterly percentage changes in these 
two variables are 15.6 and 12.3 respectively. The sample even contains changes in these two variables in excess of $100 \%$.

\section{Empirical methods and results}

This section presents estimates of the policies' effects on housing credit and house prices. We use three different empirical methods in an effort to assess the robustness of our results. The first involves conventional panel data regressions. The second uses a mean group estimator, which allows for cross-country heterogeneity in the model coefficients. The third can be described as a panel event study analysis in which the results of country-specific event studies are aggregated to estimate the average effect for the sample. We also explore the possibility of asymmetric responses to policy tightenings and loosenings.

The three methods yield similar point estimates for the policies' effects. The degree of precision varies, however, with the panel regressions producing smaller standard errors than the other two methods. To preview, we find that DSTI limits exert a significant effect on housing credit growth, a result that holds regardless of the method used. With the exception of housing-related tax changes, none of the policies consistently affects house price growth.

\subsection{Conventional panel regression analysis}

We begin with a standard reduced-form regression model of credit growth,

$$
\Delta \ln C_{i, t}=\alpha_{i}+\rho \Delta \ln C_{i, t-1}+\beta_{1} r_{i, t-1}+\beta_{2} r_{i, t-2}+\beta_{3} \Delta y_{i, t-1}+\beta_{4} \Delta y_{i, t-2}+\sum_{j=1}^{4} \gamma_{j} X_{i, t-j}+\varepsilon_{i, t}
$$

in which the quarterly credit growth rate for country $i, \Delta \ln C_{i}$, is expressed as a function of its own lag, two lags of the short-term interest rate, $r_{i}$, two lags of real personal income growth, $\Delta \ln y_{i}$, and a variable $X_{i}$ representing one (or more) of the policy variables described in Section 3. To account for cross-country differences in the average rate of credit growth, a country-specific fixed effect, $\alpha_{i}$ is included. ${ }^{13}$ An analogous specification is used for the house price, $P_{i}{ }^{14}$

\footnotetext{
${ }^{13}$ Strictly speaking, the inclusion of the lagged dependent variable would bias the fixed-effect estimator. But given the relatively long time series dimension of the data, the amount of bias should be small.

${ }^{14}$ Theoretically, the user cost model implies a cointegrating relationship between house prices and rents, which would suggest including the log of the rent-to-price ratio as an additional regressor. Results not presented in this paper indicate that the inclusion of this term has no significant effect on the parameter estimates of interest.
} 
Reduced-form regressions such as equation 24 are always susceptible to the critique that the regressors are likely to be endogenous. Specifically, policymakers may adjust interest rates or implement credit and housing-related tax policies in response to conditions in the housing market (or in response to omitted variables that are correlated with house prices or credit fluctuations). This is especially true in those economies, such as many in the Asia-Pacific region, where policymakers have actively changed LTV, provisioning and reserve requirements in their efforts to curb housing market excesses. This endogeneity may bias the parameter estimates, making it problematic to interpret the $\gamma$ coefficients as a reliable gauge of the policies' effectiveness.

Fortunately, there is reason to believe that the endogeneity problem will lead the estimates to understate the policies' effectiveness. Consider a tightening of the LTV requirement (a decrease in the maximum LTV ratio and a positive value of the LTV variable) for example. If the policy had the desired effect, it would reduce housing credit ceteris paribus. But if policymakers tended to tighten the LTV requirement when housing credit was already expanding rapidly, this would give rise to a positive correlation between our LTV variable and credit, partially (or fully) offsetting the desired policy effect. In the (implausible) limiting case in which policymakers managed to set the maximum LTV ratio in such a way as to completely stabilize credit, the estimated regression coefficient on the LTV variable would be zero. An accurate statistical assessment of the policies' effects would require some exogenous variation in the policy measures (regulatory "policy shocks"). Unfortunately, it is hard to think of any circumstances that would give rise to such exogenous policy shifts.

\subsubsection{Housing credit}

Before examining the effects of the policy variables, we estimate baseline fixed-effect regressions for housing credit and house price growth omitting the policy variables. The fitted equation for housing credit (with standard errors in parentheses)

$$
\begin{aligned}
\Delta \ln C_{i, t}= & \begin{array}{c}
0.59 \Delta \ln C_{i, t-1}-0.67 \\
(0.05)
\end{array} \\
& N=3700 \quad r_{i, t-1}+\underset{R}{0}=0.56 r_{i, t-2}+\underset{(0.19)}{0.59} \Delta y_{i, t-1}-0.004 \Delta y_{i, t-2} \\
& =0.56 \mathrm{SEE}=10.2
\end{aligned}
$$


yields reasonable estimates of housing credit dynamics and the effects of interest rates and personal income growth. With a coefficient of 0.59 on its lag, credit growth exhibits a moderate amount of positive serial correlation. Interest rate hikes slow credit growth. The negative -0.67 coefficient on $r_{t-1}$ along with the positive coefficient of 0.56 on $r_{t-2}$ (both statistically significant) together indicate that it is the change in the short-term interest rate that is relevant for credit growth, rather than the level. ${ }^{15}$ The variables are defined in such a way that the coefficients represent the effect on the annualized credit growth. A coefficient of -0.67 on the change in the interest rate therefore indicates that a 1 percentage point increase in the short-term interest rate is associated with a 0.67 percentage point reduction in credit growth in the following quarter. (Naturally, the positive coefficient on lagged credit growth implies that the medium- and long-run effects of a sustained increase in the interest rate will exceed -0.67.) Finally, the positive coefficient of 0.59 on the first lag of $\Delta y$ indicates that a one percentage point increase in the rate of personal income growth translates into an increase in the rate of housing credit growth of over half a percentage point.

Having verified the plausibility of the baseline model, the next step is to include the policy variables, $X$, in the regression. ${ }^{16}$ The results are summarized in Table 4 . It is worth noting at the outset that the numbers of each type of policy action, shown in the first numeric column of the table, are significantly smaller than those reported in Table 1 (e.g. 378 versus 717 for the general credit category). There are two reasons for this. One is the limited coverage of the time series data. As explained in Section 3, the availability of housing credit and price data varies a great deal between countries. Two of the 57 economies were excluded altogether from the credit regressions for lack of sufficient data. The spotty coverage also limits the time series dimension of the remaining 55 countries. Aggregation to the quarterly frequency also reduces the number of events. This is relevant when an action in one direction was followed within the quarter by an action in the other direction. For example, a tightening of reserve requirements in January and a loosening in March would net to zero for the quarter.

Moving to the right, the next two numeric columns (labelled "individually") summarize the estimated $\hat{\gamma}$ coefficients when each is included one at a time in the regression given by equation 24 .

\footnotetext{
${ }^{15} \mathrm{~A}$ formal statistical test fails to reject the hypothesis that $\beta_{2}=-\beta_{1}$.

${ }^{16}$ The estimated coefficients on the non-policy variables, including the interest rate, are largely unchanged by the inclusion of the policy variables.
} 
Thus, each of the seven lines in the table corresponds to a separate regression. Rather than give the individual parameter estimates, which are of little intrinsic interest, we report two functions of the estimates summarizing the magnitude of the policies' effects. One is simply the sum of the coefficients, which would represent the long-run impact of a permanent unit tightening, ignoring the dynamics. Although it provides a rough gauge of the magnitude and statistical significance of the effects, it is not particularly useful for assessing the likely effect over a policy-relevant horizon.

We therefore also report a second summary statistic constructed to gauge the expected effect on the growth rate over a one-year horizon, taking the dynamics into account. This is a function of $\hat{\gamma}_{1}$ through $\hat{\gamma}_{4}$, as well as $\hat{\rho}$ :

$$
4 \mathrm{Q} \text { effect }=\frac{1}{4}\left[\hat{\gamma}_{1}\left(1+\hat{\rho}+\hat{\rho}^{2}+\hat{\rho}^{3}\right)+\hat{\gamma}_{2}\left(1+\hat{\rho}+\hat{\rho}^{2}\right)+\hat{\gamma}_{3}(1+\hat{\rho})+\hat{\gamma}_{4}\right] .
$$

The delta method is used to calculate the standard errors.

Reassuringly, all the parameter estimates from the one-policy-at-a-time regressions have the correct (negative) sign, indicating that tightening and loosening policy actions can moderate housing credit cycles. Of these, four are statistically significant at at least the 5\% level: LTV limits, DSTI limits, exposure limits, and housing-related taxes. The largest effect comes from the DSTI limits, with a unit tightening reducing credit growth by 6.8 percentage points over the subsequent four quarters. Next come exposure limits, with a 4.6 percentage point effect. (Some caution is warranted, however, as the sample contains only 12 changes in exposure limits.) Taxes and LTV limits come in at approximately 2 percentage points.

The estimates are largely unchanged when all seven policy variables are included in the same regressions (the columns labeled "jointly"). The main difference is that the LTV limit variable is insignificant, both economically and statistically. A plausible conjecture is that DSTI and LTV requirements tend to be adjusted in tandem (as they were in China and Korea as illustrated in Figures 3 and 5) so that when included individually, the LTV variable picks up the effect of the omitted DSTI policy. This is consistent with the positive correlation between the two policies evident in Table 2.

While not a direct implication of the theoretical frameworks sketched in Section 2, there are 
reasons to suspect that tightening and loosening actions may have asymmetric effects. To the extent that reductions in reserve requirements tended to occur during economic downturns, banks may find themselves constrained by factors other than reserve requirements, such as low loan demand or an erosion of the capital base. Similar logic applies to the other policies as well. One might therefore expect loosenings to have smaller effects than tightenings.

We explore this possibility by estimating an expanded version of equation 24 in which the $X$ 's are distinguished by direction. Rather than a single $X$ with positive and negative values representing tightenings and loosenings respectively, we define two separate $X$ 's: one with positive values for tightening episodes and zero otherwise, and a second with negative values for loosenings and zero otherwise. Defined in this way, one would expect negative coefficients on both variables; the question is whether those on the loosening variable are smaller in magnitude and statistical significance.

Table 5 reports the results from a set of regressions allowing for asymmetric effects. The estimates do indeed suggest some degree of asymmetry. For three of the four policies with statistically significant effects in Table 4, the effects of tightenings are significant, while those of loosenings are not. In some cases, the coefficients on the loosening variables have the wrong sign, but in no case is the effect significant at the $5 \%$ level. Only the relaxation of exposure limits has a discernible impact. (The caveat about the small number of actions in the sample is now even more applicable.) The standard errors associated with the loosening coefficients are generally larger than those of the tightening coefficients, however. This is at least in part due to the smaller number of policy actions

(e.g. 32 tightenings but only six loosenings for DSTI limits). Consequently, the hypothesis of symmetric effects is rejected at the $5 \%$ level only for the risk-weighting variable in the individual regressions, and for the risk-weighting and LTV variables in the joint regression.

\subsubsection{House prices}

As with the credit regressions discussed in Section 4.1.1, we begin with the estimation of a fixedeffect regression for house price growth, analogous to equation 24, including the 56 economies with sufficient data. The results are as follows (with standard errors in parentheses): 


$$
\begin{aligned}
& \Delta \ln P_{i, t}=0.48 \Delta \ln P_{i, t-1}-0.49 r_{i, t-1}+0.24 r_{i, t-2}+0.60 \Delta y_{i, t-1}-0.17 \Delta y_{i, t-2} \\
& \begin{array}{llll}
(0.05) \quad(0.20) & (0.20) & (0.20)
\end{array} \\
& N=3935 \quad \bar{R}^{2}=0.30 \quad \mathrm{SEE}=10.2 \text {. }
\end{aligned}
$$

The estimates are similar to those for housing credit. Price changes are positively serially correlated, albeit somewhat less than credit growth. The coefficient on the first lag of the shortterm interest rate is negative and statistically significant; the coefficient on the second is positive, but insignificant. Finally, a 1 percentage point increase in personal income growth tends to be followed by a 0.6 percentage point increase in house prices in the subsequent quarter.

Table 6 reports the results from a set of regressions that includes the policy variables, $X .{ }^{17}$ As with housing credit, the $X$ 's are first included one by one (the "individually" columns), and then all at once (the "jointly" columns). It is evident that none of the policies has a tangible impact on house prices. The sum of the coefficients for the LTV variable is statistically significant at the $10 \%$ level, but the four-quarter effect is economically small and statistically insignificant. Exposure limits have the desired effect and the magnitudes are economically meaningful, but due to the large standard errors the hypothesis of a zero effect cannot be rejected.

Things are slightly more promising in the specification that allows for asymmetric effects of tightening and loosening actions. As shown in Table 7, the sum of the coefficients for the tightening of LTV requirements is somewhat larger than in the symmetric specification $(-4.10$ versus -2.18), but the four-quarter effect remains insignificant. Another difference is that the sum of the coefficients for increasing housing-related taxes is negative and statistically significant at the $5 \%$ level, suggesting that higher taxes slow house price growth. The estimated four-quarter effect is significant at only the $10 \%$ level, however. As in the regressions for housing credit, loosening exposure limits has a discernible positive impact on house price growth. (The caveat about the small number of actions in the sample is again applicable.) There is some evidence for asymmetric responses, with the symmetry hypothesis rejected at the 5\% level for the exposure limit and tax variables.

\footnotetext{
${ }^{17}$ The estimated coefficients on the non-policy variables are again largely unchanged by the inclusion of the policy variables.
} 


\subsection{Mean group regression analysis}

A potentially serious issue in panel regressions such as those estimated in Section 4.1 is crosscountry heterogeneity in the model parameters, which may lead to biased and inconsistent estimates. One solution to this problem is to use the mean group (MG) estimator proposed by Pesaran $\&$ Smith (1995). This involves estimating a separate time series regression for each country of the form

$$
\begin{aligned}
\Delta \ln C_{i, t}= & \alpha_{i}+\rho_{i} \Delta \ln C_{i, t-1}+ \\
& \beta_{i, 1} r_{i, t-1}+\beta_{i, 2} r_{i, t-2}+\beta_{i, 3} \Delta y_{i, t-1}+\beta_{i, 4} \Delta y_{i, t-2}+\sum_{j=1}^{4} \gamma_{i, j} X_{i, t-j}+\varepsilon_{i, t},
\end{aligned}
$$

in which the coefficients are now also indexed by $i$. (Again, we use an analogous model for house prices, $P$.) Aggregating the country-specific estimates gives the MG estimator. The aggregation can be done either on an unweighted basis, or weighted as in the random coefficient specification of Swamy (1970). Either way, the estimated parameters' covariance matrix is used in the calculation of the standard errors.

This method obviously places much greater demands on the data. First, rather than estimate nine coefficients for the entire sample, we must estimate nine coefficients for each country -513 if regressions were run on the 57 countries for which we have either credit or price data. Second, each country's time series must be long enough to allow for the estimation of equation 26 . We set the threshold for inclusion at 20 usable observations. Third, in order to estimate the relevant $\gamma$ coefficients, there must be at least one policy action in the sample for which there are sufficient time series data. Consequently, the number of degrees of freedom drops sharply both because of the loss of observations and because of the additional parameters to be estimated. It is therefore not surprising that in terms of statistical significance, the results from the MG method tend to be weaker than those from the conventional panel regressions of Section 4.1.

\subsubsection{Housing credit}

Table 8 reports the MG estimates of equation 26. As shown in the first two columns, except in the case of housing-related taxes, the loss of usable data associated with the MG method reduces 
the number of policy actions used in the estimation. Because of the requirement that each of the country-level time series regressions contains at least one policy action, the set of countries used in the calculation depends on the type of policy under consideration.

Moving rightward, the next two numeric columns in the table report the sum of the $\gamma$ 's and the four-quarter effect defined by equation 25, with an unweighted aggregation of the country-level parameter estimates. The next two contain the weighted (Swamy) estimates. ${ }^{18}$

The change in estimation method turns out to have relatively little effect on most of the parameter estimates of interest. The four-quarter effect of a unit DSTI change, for example, is -6.65 for the unweighted MG procedure versus -6.76 for the conventional panel regression. Neither is far off from the weighted estimate of -5.54 . The MG estimates are much less precise than those of the panel regression, however. This makes a tangible difference for some of the variables, especially DSTI where the standard errors are approximately twice as large. The estimated four-quarter effect goes from being statistically significant at the $1 \%$ level in the panel regression to being significant at only the 5\% level in the unweighted MG results. The remaining coefficients are statistically significant at the $10 \%$ level in the weighted results.

One sees a similar tendency in some of the other estimates, including those of the LTV and exposure limits. Somewhat surprisingly, the results turn out to be stronger for general credit policies. In that case, the unweighted estimated four-quarter effect is -1.60 (statistically significant at the $10 \%$ level) compared with a statistically insignificant -0.55 in the panel regression. The effect is not statistically significant in the weighted case, however, owing to the larger standard errors.

\subsubsection{House prices}

Table 9 reports the MG estimates of an equation analogous to 26, replacing housing credit growth with house price growth. Having obtained such weak results using conventional panel regression analysis, it is unlikely that the change in method would improve matters. As expected, with one conspicuous exception none of the estimated effects is significant at even the $10 \%$ level.

The lone exception is housing-related tax changes, which now have a large and highly statistically significant impact on house price growth. Taken at face value, an incremental tightening would slow house price growth by 3 percentage points. Unfortunately, this result disappears in

\footnotetext{
${ }^{18}$ The Rats meangroup and swamy procedures were used for the calculations.
} 
going to the weighted results, as doing so both shrinks the parameter estimates and increases the standard errors. (The event study analysis in the following section gives some insights as to why the results are sensitive to the weighting scheme.)

\subsection{Event study analysis}

The third method used to assess the policies' effects is a panel event study analysis. As discussed in MacKinlay (1997), the conventional event study involves identifying discrete events and then partitioning time series into two mutually exclusive subsamples: a set of estimation windows over which a forecasting model is fit, and a set of event windows spanning some period of time following the event. The events' effects are calculated by subtracting the forecast values from the actual values during the event window. For an event occurring in 2004Q1, for example, a four-quarter event window would span 2004Q2 through 2005Q1, and the model would be estimated on data through 2003Q4 and after 2005Q1. In a panel setting, the results from individual (in our case country-specific) event studies are aggregated to create an estimate of the average.

The event study method has several advantages over other techniques. One is that it is (arguably) less susceptible to endogeneity since the events are excluded from the estimation of the econometric model. The second is that it imposes less of a parametric structure than either the panel regression or MG methods. And like the MG technique, it allows for cross-country heterogeneity in the underlying model.

The most common use of event study analysis involves high-frequency financial data, in which

the data are plentiful and the events widely spaced. The application of the method to our study poses two challenges. One is that there are far fewer observations relative to the number of events. This reduces the amount of data in the estimation window, making it more difficult (and in some cases impossible) to estimate a reasonable forecasting model.

Closely spaced events create a second difficulty. Continuing with the previous example, the question is what to do when a second (or third) event occurs within four quarters after the first (e.g. in 2005Q1 and again in 2005Q3). In our analysis, we begin the event window one quarter after the last event in such a sequence (e.g. 2005Q4). This further reduces the number of observations available for estimating the forecasting model. It also means that the number of events is considerably smaller than the number of policy actions. In order to estimate a plausible forecasting model, 
we restrict the analysis to countries with 20 usable observations in the union of the estimation windows. The set of countries represented is therefore even narrower than in the MG analysis.

The forecasting model fitted to the data is the same as the one used in the MG analysis, equation 26 (and an analogous version for house prices). A four-quarter event window is used, making the estimates quantitatively comparable to the estimated four-quarter effects from the panel regression and MG analysis. The comparison is done on the basis of static forecasts, which use the actual data for the lagged dependent variable. ${ }^{19}$ Tightening and loosening actions are treated as distinct events, so the procedure intrinsically allows for asymmetric effects.

There are two ways to aggregate the country-level estimates. One is to take the simple, unweighted average (but still use the estimated country-specific variances in the calculation of the overall standard error). These are reported as the "unweighted" estimates. An alternative is to use the (inverse of) the country-specific standard deviations as weights (analogous to weighted least squares regression), creating the estimates reported in the "weighted" column.

\subsubsection{Housing credit}

Table 10 reports the results of the event study analysis of credit growth. The first two numeric columns show the number of countries and events used in estimating the policies' effects. Largely due to a propensity for frequent adjustments in reserve requirements, the number of general credit events is less than $20 \%$ of the number of policy actions. For the other policies, the number of distinct events is roughly one half to two thirds of the number of actions in the corresponding MG analysis.

The salient result from the table is the strong negative effect of DSTI tightening. The unweighted estimates imply that averaged across the 13 countries in the sample, a typical decrease in the maximum DSTI ratio is associated with a 3.7 percentage point reduction in the rate of real housing credit growth (4.2 percentage points for the weighted estimate). The effect is statistically significant at the $1 \%$ level. The effects are somewhat smaller but still not far from the panel regression and MG estimates. None of the other estimated tightening effects is statistically significant.

Only two DSTI loosening events survive the paring-down process, unfortunately, and so those estimates (as well as those for exposure limits) are left unreported. One anomaly is the statisti-

\footnotetext{
${ }^{19}$ Dynamic forecasts (using the fitted values as the lagged dependent variable) yield similar results.
} 
cally significant reduction in credit growth following a loosening of the LTV requirement. (Note that since the numbers represent the difference in growth rates, one would expect to see positive numbers in the loosening columns.) None of the other estimated loosening effects is significant.

The relatively small number of observations and high volatility of the dependent variable make the event study analysis highly sensitive to outliers. Nowhere is this more evident than is the response of housing credit to tightenings in general credit conditions. Each dot in Figure 6 is the estimated country-specific effect of the general credit tightening actions, ordered by size. The bars represent the $90 \%$ confidence intervals. The figure shows that most of the responses are either negative or close to zero. Bulgaria is a conspicuous outlier, however. There, housing credit continued to grow at a double-digit pace even after a 4 percentage point increase in the reserve requirement ratio in September 2007. Needless to say, it would be inappropriate to exclude anomalous observations ex post. But it is worth noting that if Bulgaria were dropped, the estimated impact on housing credit of a general credit tightening would have been a highly significant -4.7 percentage points in the unweighted case and -3.25 percentage points in the weighted case.

\subsubsection{House prices}

Table 11 presents an analogous set of results for house prices. The table shows that only housingrelated tax increases (or subsidy reductions) have statistically significant effects. The magnitudes are strikingly similar to those estimated using the MG method: -3.6 percentage points in the unweighted case (statistically significant at the $1 \%$ level) and -1.9 percentage points in the weighted case (significant at the $10 \%$ level).

A recurring theme in both the MG and event study analyses is the difference between the weighted and unweighted estimates. Figure 7 illustrates the reason for this discrepancy. (As in Figure 6, the dots are the estimated country-specific effects and the bars represent the $90 \%$ confidence intervals.) The overall tendency is clearly negative. And although zero is within the confidence interval for all but two of the countries, the simple average is statistically significant. A number

of the large negative responses are associated with large standard errors, however. The weighted procedure discounts these observations proportionally, which tends to shrink the estimates. 


\section{Conclusions}

Utilizing a new database of credit and housing-related tax policy measures and three alternative econometric approaches, this paper has provided a systemic assessment of the efficacy of credit and housing-related tax policies on housing credit and house prices. The evidence shows that certain types of targeted credit and/or tax policies can affect the housing market, and could potentially be used as tools to promote financial and macroeconomic stability.

Using conventional panel regressions, we found that housing credit responds in the expected way to changes in the maximum DSTI ratio, the maximum LTV ratio, exposure limits, and housingrelated taxes. However, these results are somewhat sensitive to the choice of econometric technique. In the MG and event study analyses, only changes in the maximum DSTI ratio have statistically significant effects on housing credit. Depending on the method used, an incremental tightening in the DSTI ratio is associated with a 4 to 7 percentage point deceleration in credit growth over the following year. Loosenings have a comparable but imprecisely estimated effect in the opposite direction. An increase in housing-related taxes is the only policy with a measurable impact on house prices, with an incremental tightening associated with a 2 to 3 percentage point reduction in house price growth. Tax reductions have no discernible impact on house prices.

From a policy perspective, the negative results are in some respects as important as the positive ones. One such finding is that instruments affecting the supply of credit generally by increasing the cost of providing housing loans (reserve and liquidity requirements and limits on credit growth) have little or no detectable effect on the housing market. Nor do risk-weighting and provisioning requirements, which target the supply of housing credit. Exposure limits, which work not by the cost of lending but through the quantity restrictions on banks' loan supply, may be an exception in this regard, although the small number of documented policy actions makes it hard to draw firm conclusions. Measures aimed at controlling credit supply are therefore likely to be ineffective.

Of the two policies targeted at the demand side of the market, the evidence indicates that reductions in the maximum LTV ratio do less to slow credit growth than lowering the maximum DSTI ratio does. This may be because during housing booms, rising prices increase the amount that can be borrowed, partially or wholly offsetting any tightening of the LTV ratio.

None of the policies designed to affect either the supply of or the demand for credit has a dis- 
cernible impact on house prices. This has implications for the degree to which credit-constrained households are the marginal purchasers of housing or for the importance of housing supply, which is not explicitly considered in this study. Only tax changes affecting the cost of buying a house, which bear directly on the user cost, have any measurable effect on prices.

These conclusions all pertain to the policies' average effects in a sample of 57 heterogeneous economies. There is no reason to believe the effects will be the same everywhere, of course. A policy that is ineffective in one country may be highly effective in another, and vice versa. The essential next step is to understand how policy effectiveness is influenced, narrowly, by legal, institutional and financial structural features of the housing market and, more broadly, by the financial system. 


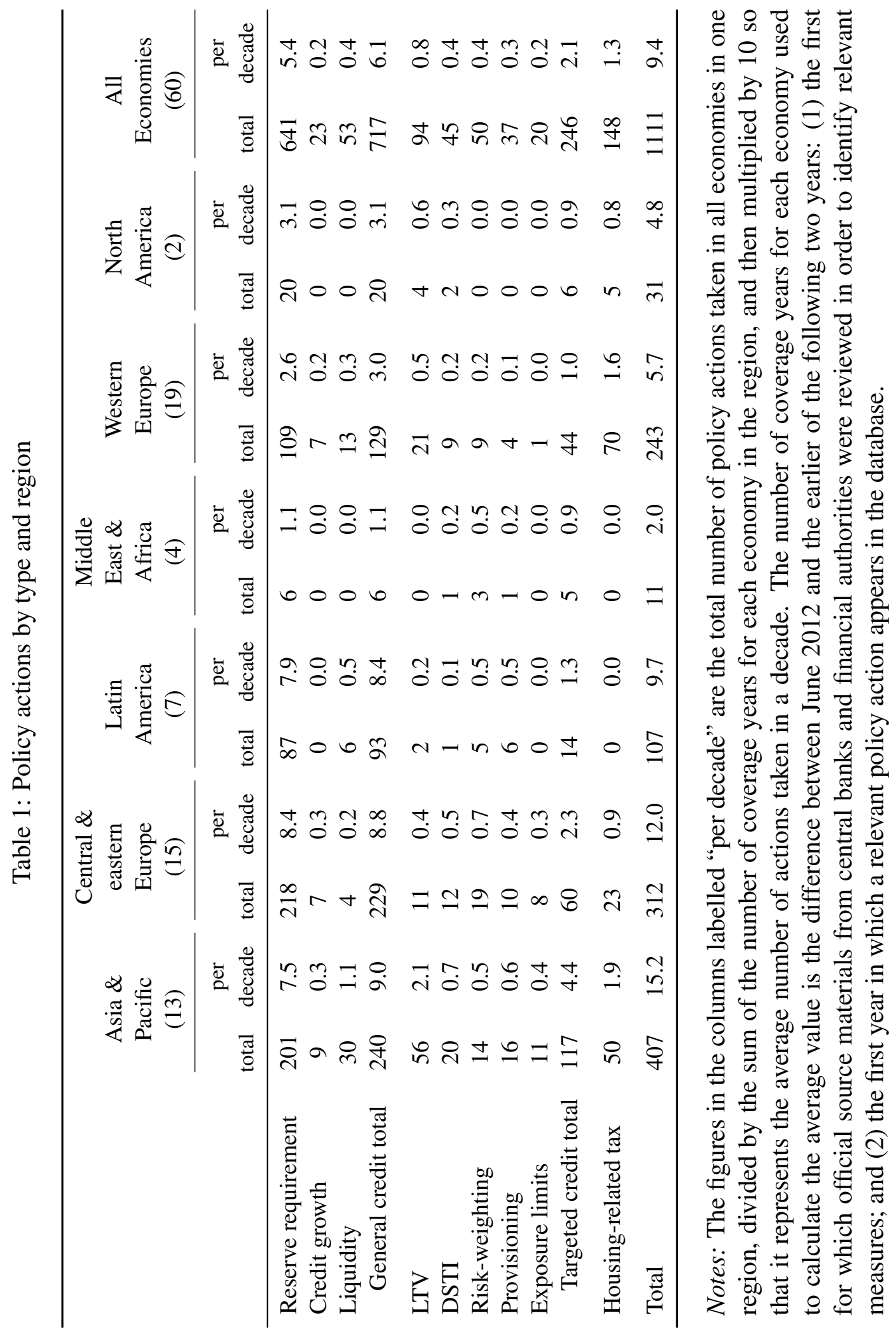


Table 2: Correlations between policy measures

A. Policy changes

\begin{tabular}{lrcrcccc}
\hline & Gen cred & LTV & DSTI & Expo lim & Risk wt & Prov & Tax \\
\hline General credit & 1 & & & & & & \\
LTV ratio & 0.08 & 1 & & & & & \\
DSTI ratio & 0.07 & 0.37 & 1 & & & & \\
Exposure limits & -0.01 & 0.06 & 0.12 & 1 & & & \\
Risk-weighting & 0.03 & 0.03 & -0.00 & 0.12 & 1 & & \\
Provisioning & 0.04 & 0.06 & 0.02 & 0.09 & -0.00 & 1 & \\
Housing-related tax & 0.01 & 0.11 & 0.03 & 0.00 & 0.00 & 0.00 & 1 \\
\hline
\end{tabular}

B. Cumulative policy indicators

\begin{tabular}{lccccccc}
\hline & Gen cred & LTV & DSTI & Expo lim & Risk wt & Prov & Tax \\
\hline General credit & 1 & & & & & & \\
LTV ratio & 0.08 & 1 & & & & & \\
DSTI ratio & 0.15 & 0.58 & 1 & & & & \\
Exposure limits & -0.11 & 0.07 & 0.11 & 1 & & & \\
Risk-weighting & 0.01 & 0.08 & 0.08 & -0.06 & 1 & & \\
Provisioning & 0.08 & 0.23 & 0.29 & 0.04 & 0.13 & 1 & \\
Housing-related tax & -0.01 & 0.00 & 0.15 & -0.00 & -0.00 & 0.06 & 1 \\
\hline
\end{tabular}

Notes: The correlations are calculated for the 57 countries used in the empirical analysis. Panel A shows the correlations between the discrete policy change variables. The underlying monthly data are summed to obtain quarterly series. Panel B shows the correlations between the cumulative policy indicators, created by accumulating the policy change variables. 
Table 3: Descriptive statistics

\begin{tabular}{lcrrrrrrr}
\hline & & \multicolumn{7}{c}{ Fractiles } \\
\cline { 6 - 7 } Variable & Mean & SD & $50 \%$ & $5 \%$ & $95 \%$ & Min & Max & Obs \\
\hline Real housing credit growth & 9.5 & 15.6 & 7.2 & -7.9 & 38.3 & -81.5 & 116.2 & 3730 \\
Real house price growth & 2.0 & 12.3 & 1.6 & -15.2 & 20.6 & -100.7 & 101.7 & 4067 \\
Real personal income growth & 2.4 & 3.2 & 2.5 & -2.8 & 7.8 & -19.3 & 14.8 & 4447 \\
Short-term interest rate & 6.3 & 5.3 & 4.8 & 0.5 & 17.4 & 0.0 & 39.5 & 4363 \\
Inflation rate & 4.3 & 4.7 & 3.1 & -0.6 & 13.6 & -11.7 & 33.4 & 4556 \\
\hline
\end{tabular}

Notes: Housing credit growth, house price growth, real income growth and inflation are expressed in annualized quarterly growth rates in percentage terms. The interest rates are expressed in percentage terms. The sample covers the period with valid data for either housing credit or house prices, whose start dates are given in Appendix Table 2.

Table 4: Panel regression results for housing credit with symmetric effects

\begin{tabular}{|c|c|c|c|c|c|}
\hline \multirow[b]{2}{*}{ Policy } & \multirow[b]{2}{*}{ Actions } & \multicolumn{2}{|c|}{ Individually } & \multicolumn{2}{|c|}{ Jointly } \\
\hline & & Sum & $4 Q$ & Sum & $4 Q$ \\
\hline General credit & 378 & $\begin{array}{c}-1.58 \\
(1.14)\end{array}$ & $\begin{array}{r}-0.55 \\
(0.51)\end{array}$ & $\begin{array}{r}-1.24 \\
(1.44)\end{array}$ & $\begin{array}{r}-0.37 \\
(0.49)\end{array}$ \\
\hline LTV limits & 80 & $\begin{array}{c}-4.69^{* * *} \\
(1.80)\end{array}$ & $\begin{array}{c}-2.11^{* *} \\
(0.85)\end{array}$ & $\begin{array}{c}-0.29 \\
(2.16)\end{array}$ & $\begin{array}{r}-0.04 \\
(1.03)\end{array}$ \\
\hline DSTI limits & 38 & $\begin{array}{c}-14.19^{* * *} \\
(3.52)\end{array}$ & $\begin{array}{c}-6.76^{* * *} \\
(1.67)\end{array}$ & $\begin{array}{c}-12.74^{* * *} \\
(4.19)\end{array}$ & $\begin{array}{c}-6.19^{* * *} \\
(1.92)\end{array}$ \\
\hline Exposure limits & 12 & $\begin{array}{c}-10.94^{* * *} \\
(2.70)\end{array}$ & $\begin{array}{c}-4.64^{* * *} \\
(1.62)\end{array}$ & $\begin{array}{c}-10.34^{* * *} \\
(2.99)\end{array}$ & $\begin{array}{c}-4.41^{* * *} \\
(1.76)\end{array}$ \\
\hline Risk-weighting & 44 & $\begin{array}{c}-1.46 \\
(3.84)\end{array}$ & $\begin{array}{r}-0.63 \\
(1.53)\end{array}$ & $\begin{array}{c}0.20 \\
(4.11)\end{array}$ & $\begin{array}{c}0.05 \\
(0.96)\end{array}$ \\
\hline Provisioning & 28 & $\begin{array}{r}-3.38 \\
(3.95)\end{array}$ & $\begin{array}{r}-1.24 \\
(1.66)\end{array}$ & $\begin{array}{c}-2.99 \\
(4.19)\end{array}$ & $\begin{array}{r}-1.03 \\
(1.74)\end{array}$ \\
\hline Housing-related tax & 108 & $\begin{array}{c}-5.24^{* *} \\
(2.46)\end{array}$ & $\begin{array}{c}-2.39^{* *} \\
(1.09)\end{array}$ & $\begin{array}{c}-5.03^{* *} \\
(2.48)\end{array}$ & $\begin{array}{c}-2.28^{* *} \\
(1.09)\end{array}$ \\
\hline
\end{tabular}

Notes: The dependent variable is annualized quarterly growth rate in real housing credit. Robust standard errors are in parentheses. Asterisks indicate statistical significance: *** for $1 \%, * *$ for $5 \%$ and $*$ for $10 \%$. 


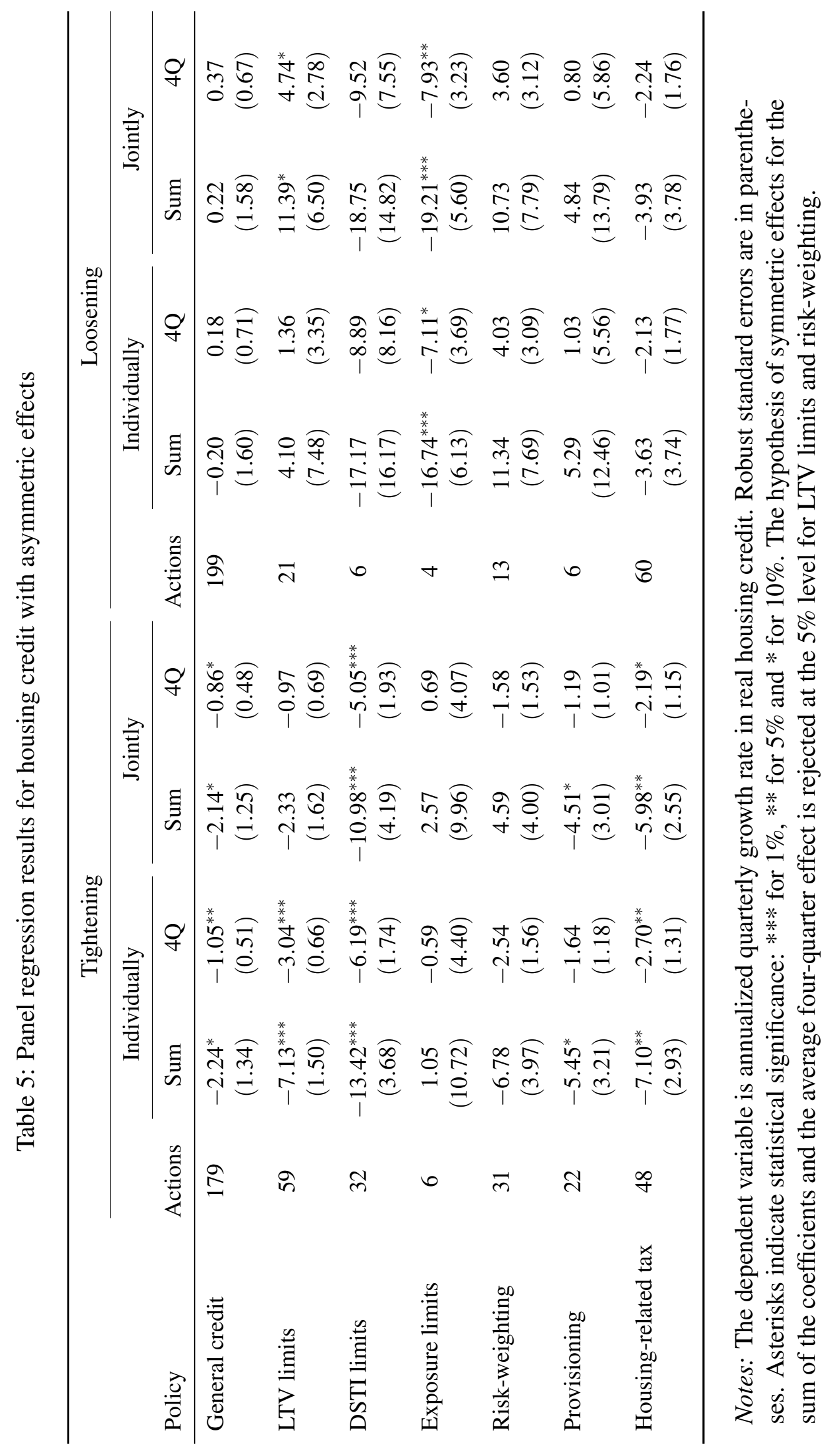


Table 6: Panel regression results for house prices with symmetric effects

\begin{tabular}{|c|c|c|c|c|c|}
\hline \multirow[b]{2}{*}{ Policy } & \multirow[b]{2}{*}{ Actions } & \multicolumn{2}{|c|}{ Individually } & \multicolumn{2}{|c|}{ Jointly } \\
\hline & & Sum & $4 Q$ & Sum & $4 Q$ \\
\hline General credit & 420 & $\begin{array}{c}-0.37 \\
(0.82)\end{array}$ & $\begin{array}{c}-0.07 \\
(0.31)\end{array}$ & $\begin{array}{c}-0.24 \\
(0.80)\end{array}$ & $\begin{array}{c}-0.01 \\
(0.30)\end{array}$ \\
\hline LTV limits & 85 & $\begin{array}{r}-2.18^{*} \\
(1.20)\end{array}$ & $\begin{array}{c}-0.58 \\
(0.55)\end{array}$ & $\begin{array}{c}-2.01 \\
(1.98)\end{array}$ & $\begin{array}{c}-0.54 \\
(0.84)\end{array}$ \\
\hline DSTI limits & 42 & $\begin{array}{c}-2.67 \\
(4.17)\end{array}$ & $\begin{array}{c}-0.70 \\
(1.54)\end{array}$ & $\begin{array}{c}-1.70 \\
(4.91)\end{array}$ & $\begin{array}{c}-0.47 \\
(1.86)\end{array}$ \\
\hline Exposure limits & 19 & $\begin{array}{c}-7.62 \\
(6.83)\end{array}$ & $\begin{array}{c}-3.18 \\
(2.94)\end{array}$ & $\begin{array}{c}-8.76 \\
(6.78)\end{array}$ & $\begin{array}{r}-3.56 \\
(2.99)\end{array}$ \\
\hline Risk-weighting & 45 & $\begin{array}{c}6.99 \\
(4.39)\end{array}$ & $\begin{array}{c}1.71 \\
(1.70)\end{array}$ & $\begin{array}{r}8.07^{*} \\
(4.42)\end{array}$ & $\begin{array}{c}2.08 \\
(1.71)\end{array}$ \\
\hline Provisioning & 34 & $\begin{array}{c}-0.61 \\
(3.18)\end{array}$ & $\begin{array}{c}-0.58 \\
(1.34)\end{array}$ & $\begin{array}{c}-0.63 \\
(3.29)\end{array}$ & $\begin{array}{c}-0.52 \\
(1.33)\end{array}$ \\
\hline Housing-related tax & 120 & $\begin{array}{c}-1.34 \\
(1.46)\end{array}$ & $\begin{array}{c}-0.33 \\
(0.53)\end{array}$ & $\begin{array}{c}-1.24 \\
(1.54)\end{array}$ & $\begin{array}{c}-0.32 \\
(0.60)\end{array}$ \\
\hline
\end{tabular}

Notes: The dependent variable is annualized quarterly growth rate in the real house price. Robust standard errors are in parentheses. Asterisks indicate statistical significance: $* * *$ for $1 \%, * *$ for $5 \%$ and $*$ for $10 \%$. 


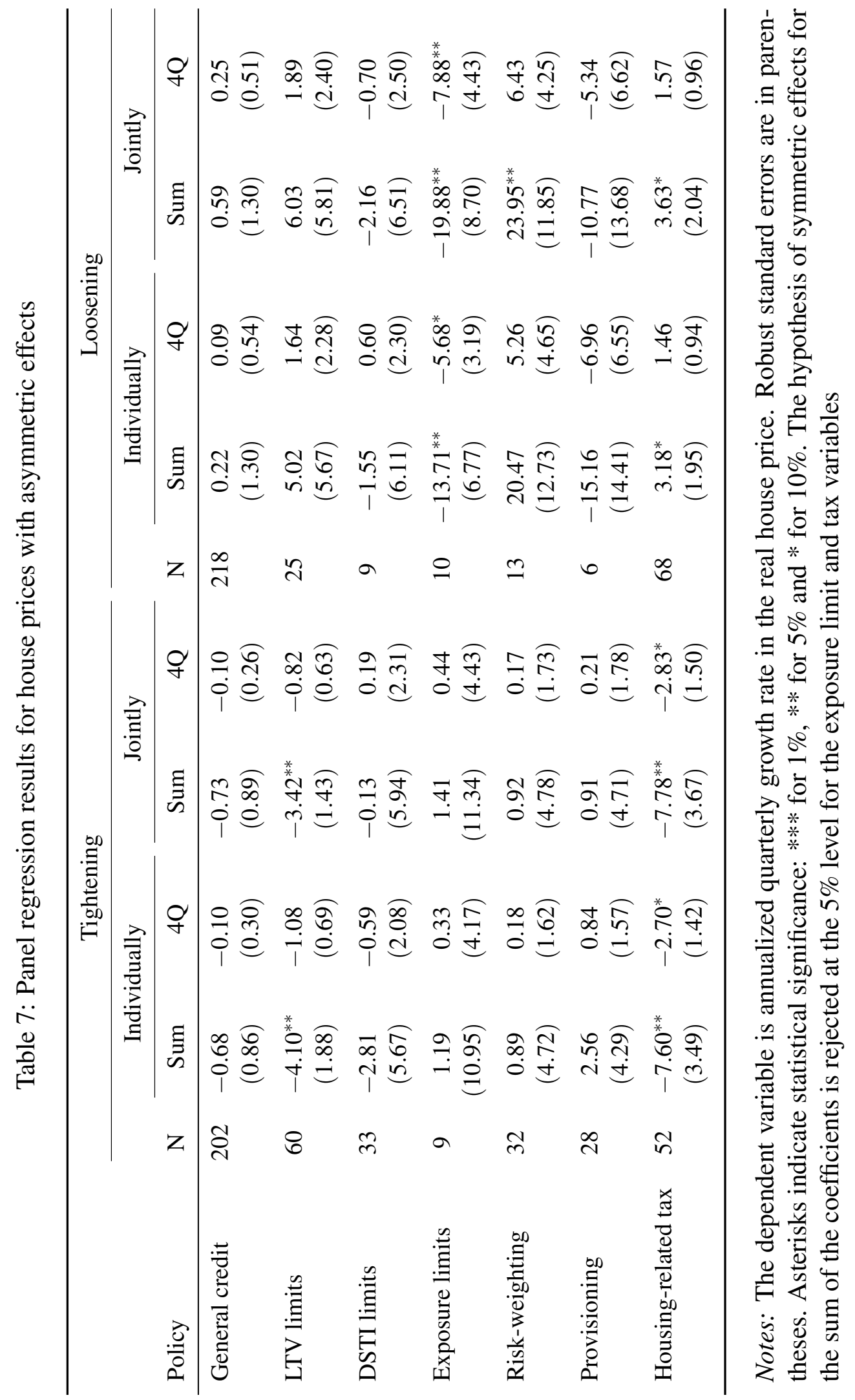


Table 8: Mean group regression results for housing credit

\begin{tabular}{|c|c|c|c|c|c|c|}
\hline \multirow[b]{2}{*}{ Policy } & \multirow[b]{2}{*}{ Countries } & \multirow[b]{2}{*}{ Actions } & \multicolumn{2}{|c|}{ Unweighted } & \multicolumn{2}{|c|}{ Weighted } \\
\hline & & & Sum & $4 Q$ & Sum & $4 \mathrm{Q}$ \\
\hline General credit & 42 & 349 & $\begin{array}{c}-4.18^{* *} \\
(2.13)\end{array}$ & $\begin{array}{r}-1.60^{*} \\
(0.90)\end{array}$ & $\begin{array}{r}-3.47 \\
(2.91)\end{array}$ & $\begin{array}{r}-1.43 \\
(1.20)\end{array}$ \\
\hline LTV limits & 23 & 77 & $\begin{array}{c}0.24 \\
(4.32)\end{array}$ & $\begin{array}{c}0.09 \\
(1.81)\end{array}$ & $\begin{array}{r}-0.16 \\
(5.85)\end{array}$ & $\begin{array}{r}-0.23 \\
(2.52)\end{array}$ \\
\hline DSTI limits & 15 & 35 & $\begin{array}{r}-13.69^{*} \\
(7.08)\end{array}$ & $\begin{array}{c}-6.65^{* *} \\
(3.06)\end{array}$ & $\begin{array}{r}-11.61^{*} \\
(6.57)\end{array}$ & $\begin{array}{r}-5.54^{*} \\
(3.33)\end{array}$ \\
\hline Exposure limits & 6 & 10 & $\begin{array}{r}-7.71 \\
(7.62)\end{array}$ & $\begin{array}{c}-2.98 \\
(3.14)\end{array}$ & $\begin{array}{r}-6.89 \\
(7.81)\end{array}$ & $\begin{array}{r}-2.72 \\
(3.34)\end{array}$ \\
\hline Risk-weighting & 22 & 42 & $\begin{array}{r}-7.57^{*} \\
(3.98)\end{array}$ & $\begin{array}{r}-2.93^{*} \\
(1.73)\end{array}$ & $\begin{array}{c}-5.28 \\
(4.41)\end{array}$ & $\begin{array}{c}-2.00 \\
(2.00)\end{array}$ \\
\hline Provisioning & 12 & 24 & $\begin{array}{c}0.05 \\
(6.93)\end{array}$ & $\begin{array}{c}-0.43 \\
(3.25)\end{array}$ & $\begin{array}{c}0.33 \\
(5.86)\end{array}$ & $\begin{array}{r}-0.35 \\
(2.79)\end{array}$ \\
\hline Housing-related tax & 28 & 108 & $\begin{array}{c}-3.05 \\
(2.46)\end{array}$ & $\begin{array}{r}-1.47 \\
(1.06)\end{array}$ & $\begin{array}{r}-2.48 \\
(2.92)\end{array}$ & $\begin{array}{r}-1.19 \\
(1.30)\end{array}$ \\
\hline
\end{tabular}

Notes: The dependent variable is annualized quarterly growth rate in real housing credit. Standard errors are in parentheses. Asterisks indicate statistical significance: *** for $1 \%$, ** for $5 \%$ and $*$ for $10 \%$. 
Table 9: Mean group regression results for house prices

\begin{tabular}{|c|c|c|c|c|c|c|}
\hline \multirow[b]{2}{*}{ Policy } & \multirow[b]{2}{*}{ Countries } & \multirow[b]{2}{*}{ Actions } & \multicolumn{2}{|c|}{ Unweighted } & \multicolumn{2}{|c|}{ Weighted } \\
\hline & & & Sum & $4 Q$ & Sum & $4 Q$ \\
\hline General credit & 47 & 404 & $\begin{array}{r}-1.72 \\
(1.86)\end{array}$ & $\begin{array}{r}-0.52 \\
(0.68)\end{array}$ & $\begin{array}{c}-0.45 \\
(2.28)\end{array}$ & $\begin{array}{r}-0.10 \\
(0.89)\end{array}$ \\
\hline LTV limits & 25 & 79 & $\begin{array}{c}6.40 \\
(4.09)\end{array}$ & $\begin{array}{c}2.54^{*} \\
(1.49)\end{array}$ & $\begin{array}{c}3.80 \\
(3.97)\end{array}$ & $\begin{array}{c}1.67 \\
(1.50)\end{array}$ \\
\hline DSTI limits & 17 & 41 & $\begin{array}{r}-0.27 \\
(6.39)\end{array}$ & $\begin{array}{c}0.09 \\
(2.59)\end{array}$ & $\begin{array}{r}-0.67 \\
(7.19)\end{array}$ & $\begin{array}{c}0.07 \\
(2.90)\end{array}$ \\
\hline Exposure limits & 7 & 15 & $\begin{array}{c}5.82 \\
(10.65)\end{array}$ & $\begin{array}{c}1.28 \\
(3.89)\end{array}$ & $\begin{array}{c}4.17 \\
(14.08)\end{array}$ & $\begin{array}{c}0.80 \\
(5.57)\end{array}$ \\
\hline Risk-weighting & 21 & 40 & $\begin{array}{c}1.21 \\
(4.96)\end{array}$ & $\begin{array}{r}-0.10 \\
(1.86)\end{array}$ & $\begin{array}{c}2.33 \\
(5.10)\end{array}$ & $\begin{array}{c}0.45 \\
(1.93)\end{array}$ \\
\hline Provisioning & 14 & 30 & $\begin{array}{r}-0.99 \\
(6.46)\end{array}$ & $\begin{array}{c}-0.38 \\
(2.24)\end{array}$ & $\begin{array}{r}-1.83 \\
(6.66)\end{array}$ & $\begin{array}{r}-0.65 \\
(2.40)\end{array}$ \\
\hline Housing-related tax & 31 & 119 & $\begin{array}{c}-7.75^{\text {*** }} \\
(2.85)\end{array}$ & $\begin{array}{c}-3.05^{* * *} \\
(1.09)\end{array}$ & $\begin{array}{r}-4.73 \\
(4.02)\end{array}$ & $\begin{array}{r}-1.87 \\
(1.72)\end{array}$ \\
\hline
\end{tabular}

Notes: The dependent variable is annualized quarterly growth rate in the real house price. Standard errors are in parentheses. Asterisks indicate statistical significance: $* * *$ for $1 \%$, ** for $5 \%$ and $*$ for $10 \%$. 


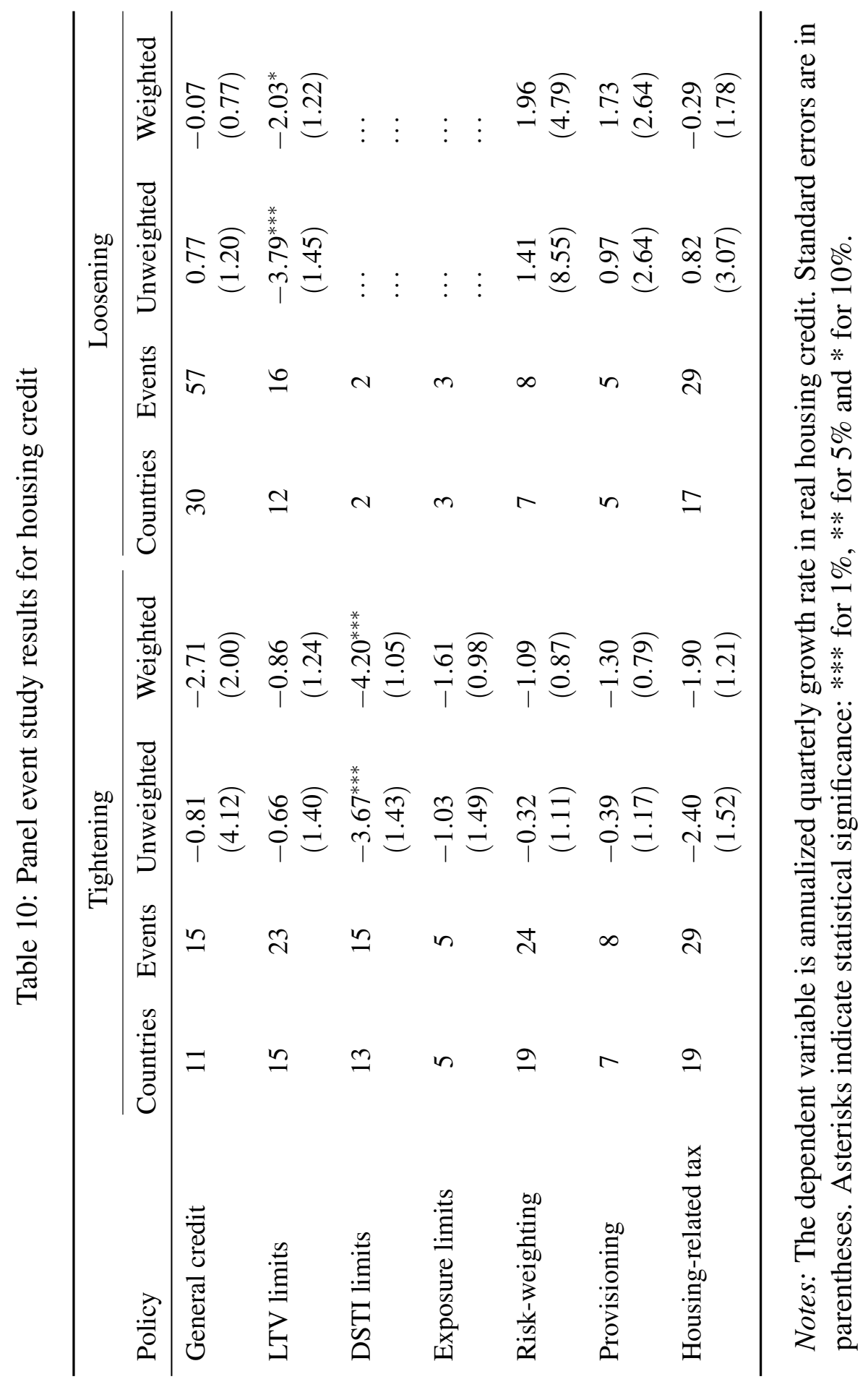




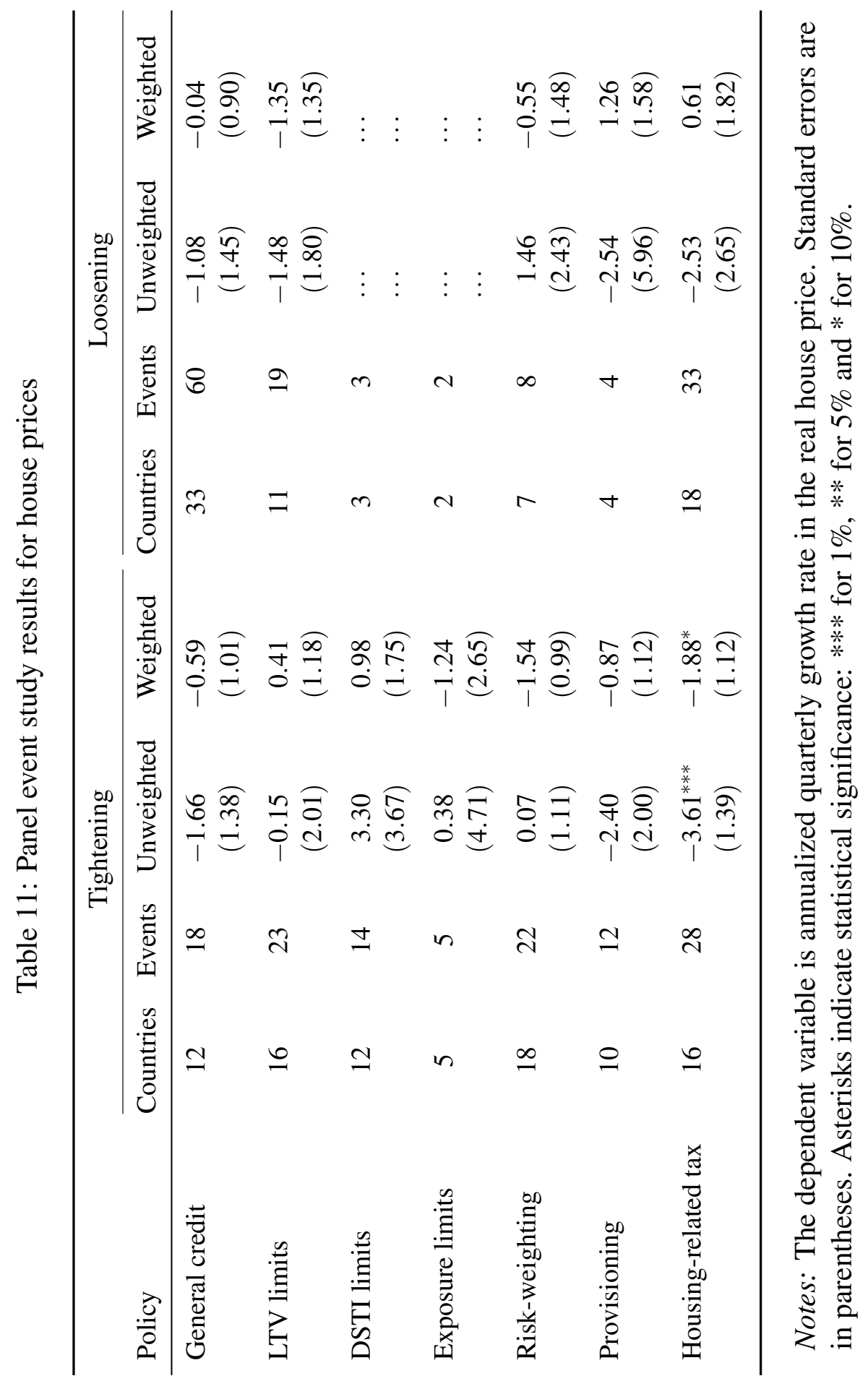


Figure 1: The cross-country distribution of policy actions

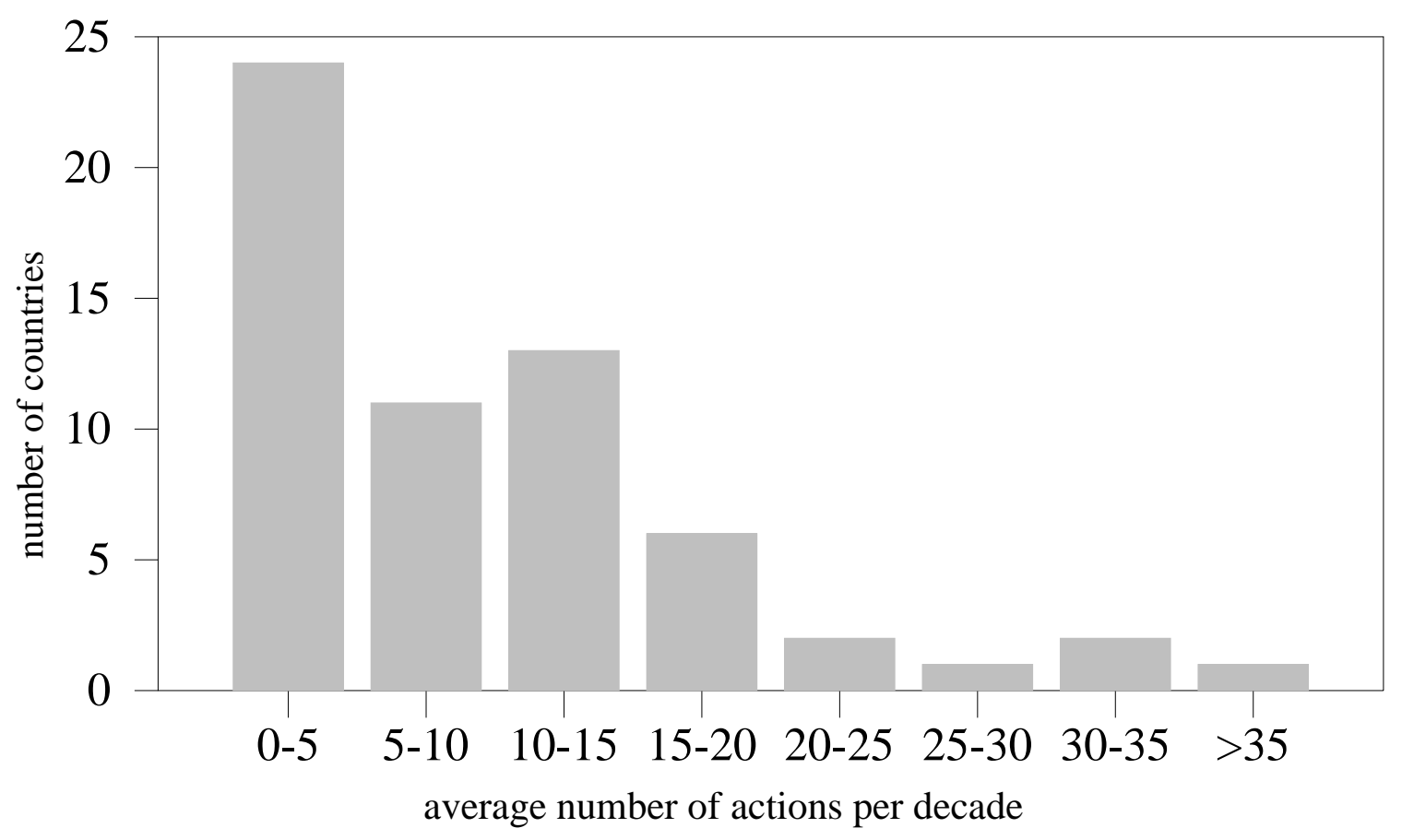

Notes: The figure plots the cross-country distribution of the total number of policy actions, scaled to represent the average number per decade. The decadal averages are calculated as the absolute number of policy actions taken in each country, divided by the sum of the number of coverage years, and then multiplied by 10 . The number of coverage years for each economy used to calculate the average value is the difference between June 2012 and the earlier of the following two years: (1) the first for which official source materials from central banks and financial authorities were reviewed in order to identify relevant measures; and (2) the first year in which a relevant policy action appears in the database. 


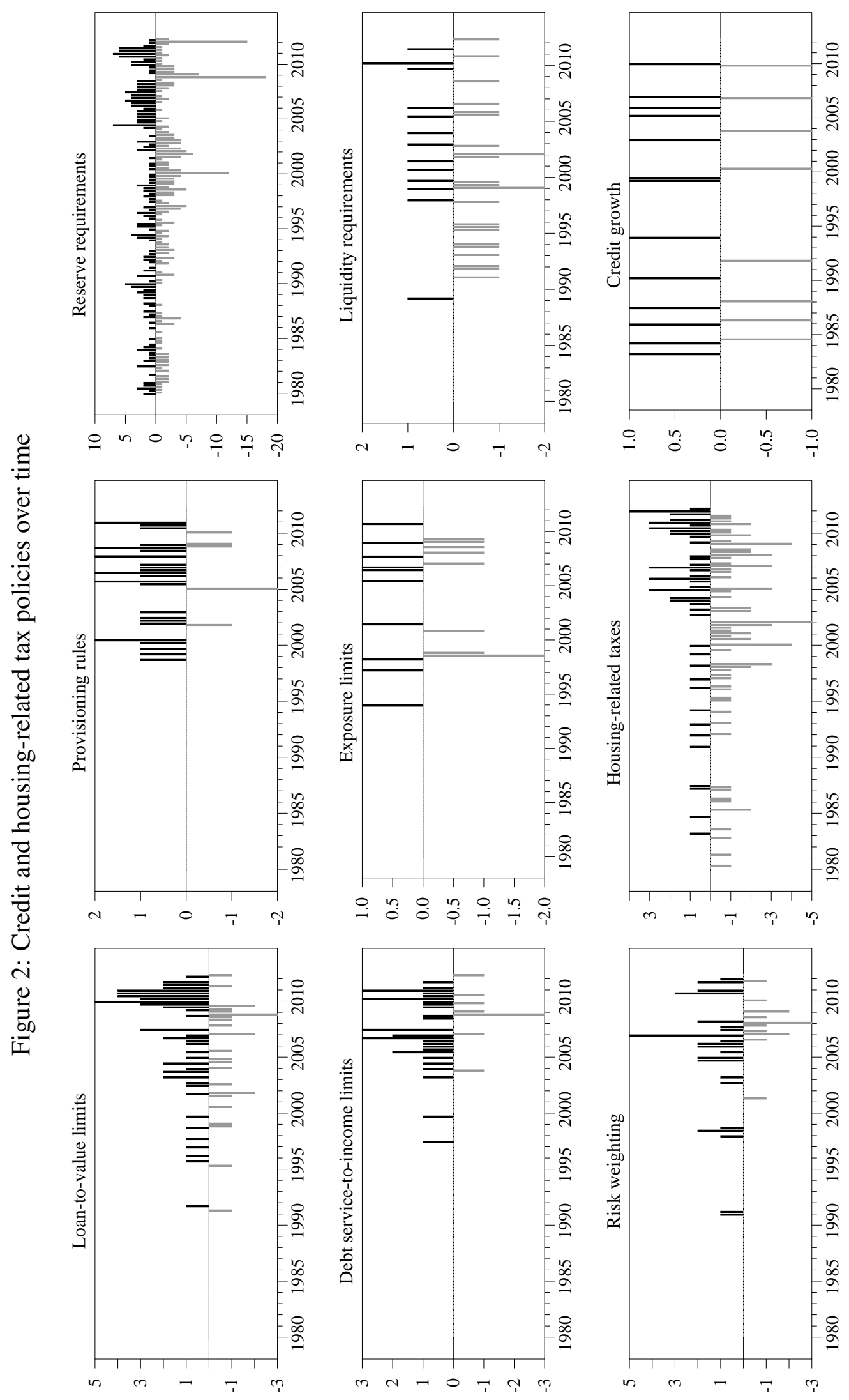

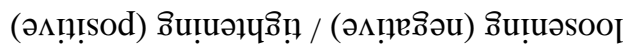


Figure 3: Interest rate and credit policies in China

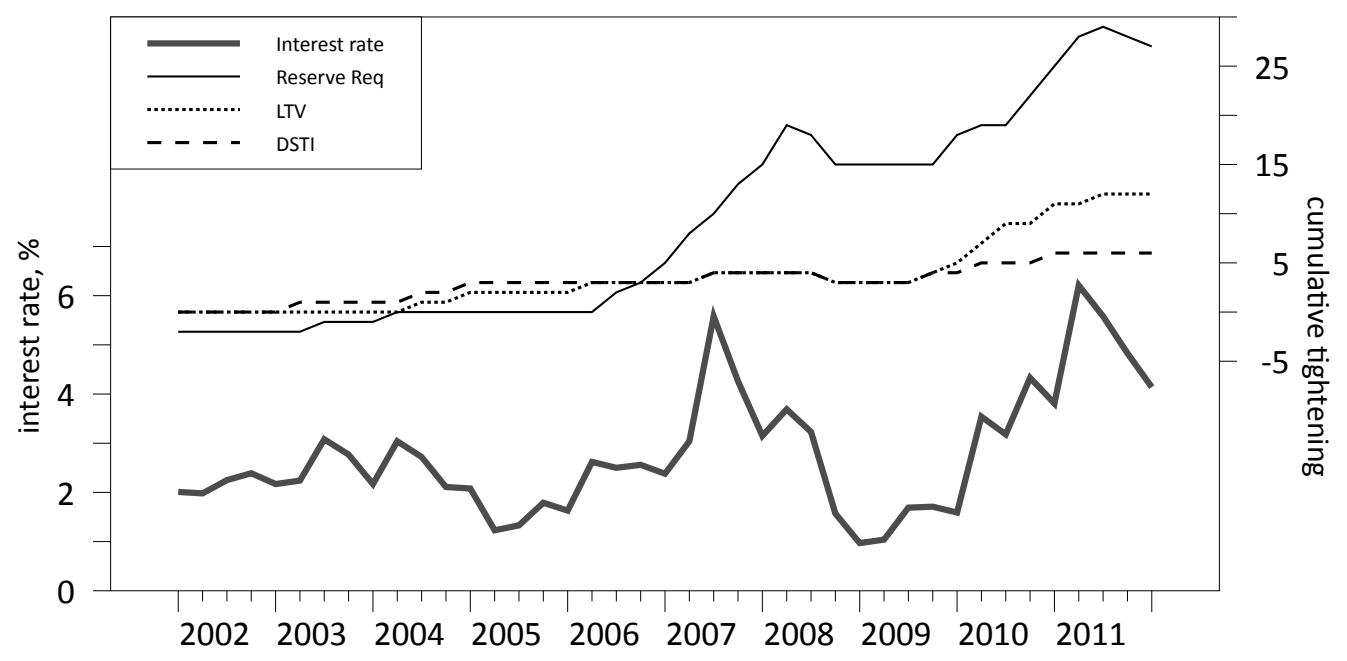

Figure 4: Interest rate, credit and housing-related tax policies in Hong Kong SAR

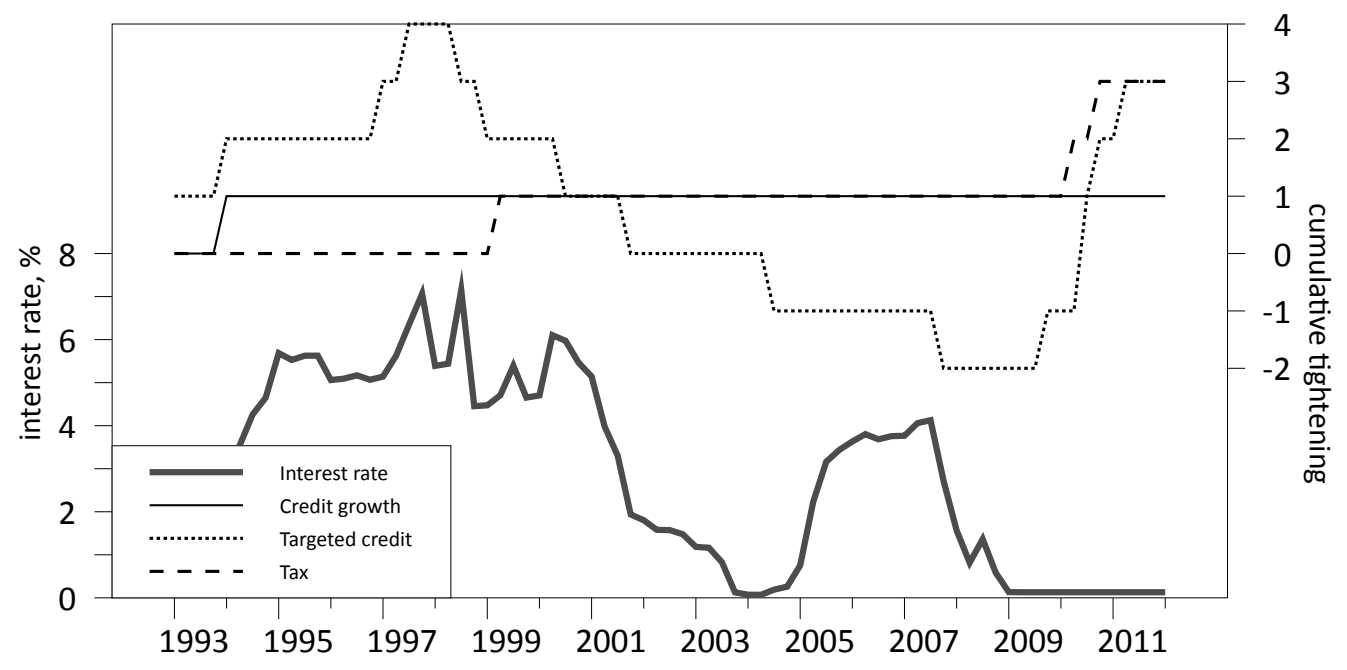


Figure 5: Interest rate and credit policies in Korea

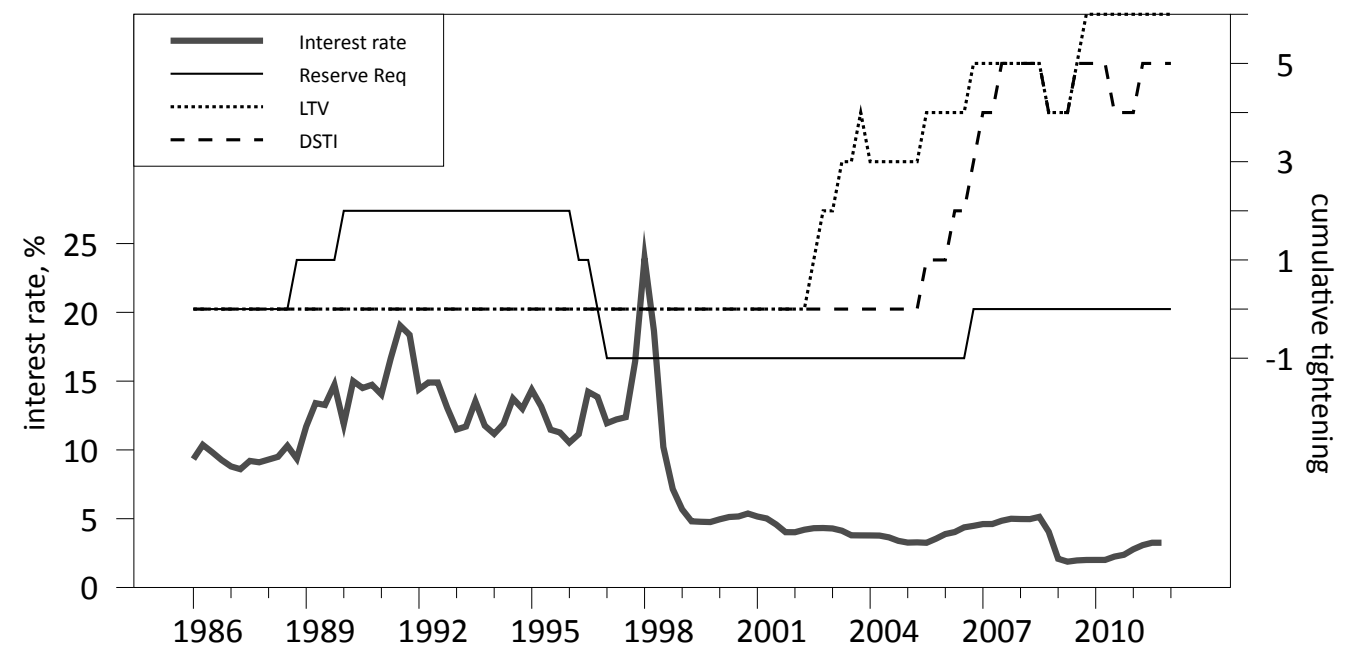

Figure 6: Event study responses of housing credit to a general credit tightening

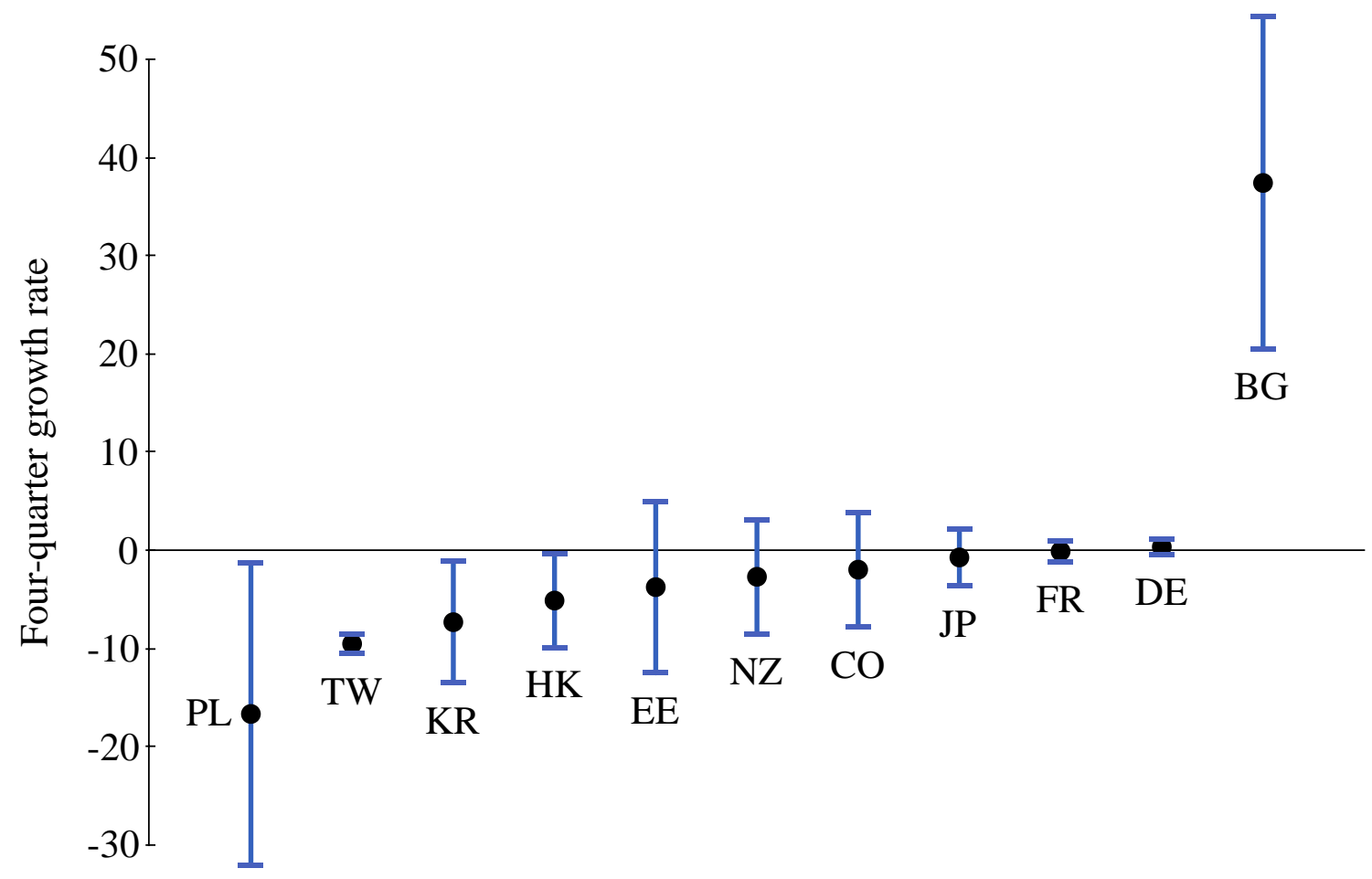

Notes: $\mathrm{BG}=$ Bulgaria $; \mathrm{CO}=$ Colombia; $\mathrm{DE}=$ Germany $; \mathrm{EE}=$ Estonia; $\mathrm{FR}=$ France $; \mathrm{HK}$ $=$ Hong Kong SAR; JP = Japan; KR = Korea; NZ = New Zealand; PL = Poland; TW = Chinese Taipei. 
Figure 7: Event study responses of house prices to housing-related tax increases

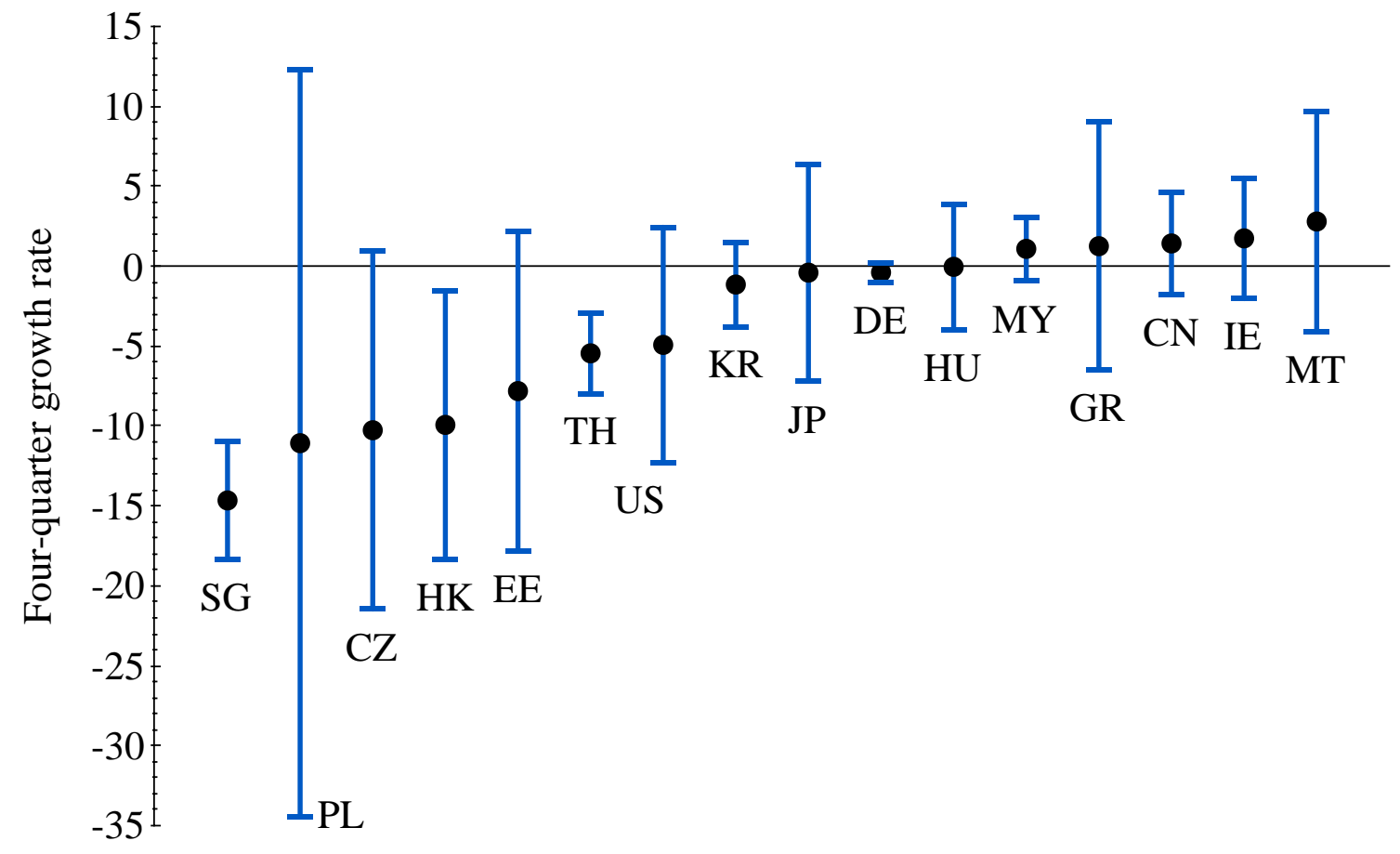

Notes: $\mathrm{CN}=$ China; $\mathrm{CZ}=$ Czech Republic; $\mathrm{DE}=$ Germany; $\mathrm{EE}=$ Estonia; $\mathrm{GR}=$ Greece; $\mathrm{HK}=$ Hong Kong SAR; HU = Hungary; IE = Ireland; JP = Japan; KR = Korea; MT = Malta; MY = Malaysia; $\mathrm{PL}=$ Poland $\mathrm{SG}=$ Singapore; $\mathrm{TH}=$ Thailand $; \mathrm{US}=$ United States. 


\section{References}

Bernanke, Ben S. 2010. Monetary Policy and the Housing Bubble. Speech delivered to the annual meeting of the American Economic Association, January 3.

Bernanke, Ben S., \& Gertler, Mark. 1999. Monetary Policy and Asset Price Volatility. Pages 77-128 of: New Challenges for Monetary Policy. Jackson Hole Symposium. Federal Reserve Bank of Kansas City.

Blanchard, Olivier J., Dell'Ariccia, Giovanni, \& Mauro, Paolo. 2010. Rethinking Macroeconomic Policy. Journal of Money, Credit and Banking, 42, 199-215.

Borio, Claudio. 2011. Central Banking Post-Crisis: What Compass for Uncharted Waters? In: Jones, Claire, \& Pringle, Robert (eds), The Future of Central Banking. Central Bank Publications.

Borio, Claudio, \& Shim, Ilhyock. 2007. What Can (Macro-)prudential policy do to support monetary policy? Working Paper 242. Bank for International Settlements.

Claessens, Stijn, Ghosh, Swati R., \& Mihet, Roxana. 2013. Macro-Prudential Policies to Mitigate Financial System Vulnerabilities. Journal of International Money and Finance, forthcoming.

Crowe, Cristopher, Dell' Ariccia, Giovanni, Igan, Deniz, \& Rabanal, Pau. 2011. How to Deal with Real Estate Booms: Lessons from Country Experiences. Working Paper 11/91. International Monetary Fund.

Eichengreen, Barry, El-Erian, Mohamed, Fraga, Arminio, Ito, Takatoshi, Pisani-Ferry, Jean, Prasad, Eswar, Rajan, Raghuram G., Ramos, Mara, Reinhart, Carmen M., Rodrik, Dani, Rogoff, Kenneth S., Shin, Hyun Song, Velasco, Andrés, \& Yu, Yongding. 2011. Rethinking Central Banking: Committee on International Economic Policy and Reform. The Brookings Institution.

Galí, Jordi. 2013. Monetary Policy and Rational Asset Price Bubbles. American Economic Review, forthcoming.

Hilbers, Paul, Otker-Robe, Inci, Pazarbasioglu, Ceyla, \& Johnsen, Gudrun. 2005. Assessing and Managing Rapid Credit Growth and the Role of Supervisory and Prudential Policies. Working Paper 05/151. International Monetary Fund.

IMF-BIS-Financial Stability Board. 2011 (October). Macroprudential Policy Tools and Frameworks. Progress Report to G20.

Ito, Takatoshi. 2010. Monetary Policy and Financial Stability: Is Inflation Targeting Passé? Working Paper 206. Asian Development Bank.

King, Mervyn. 2013 (April). Monetary Policy: Many Targets, Many Instruments, Where Do We Stand? Remarks at the IMF Conference on Rethinking Macro Policy II: First Steps and Early Lessons. 
Kuttner, Kenneth N. 2014. Low Interest Rates and Housing Bubbles: Still No Smoking Gun. Chap. 8, pages 159-185 of: Evanoff, Douglas D. (ed), The Role of Central Banks in Financial Stability: How Has It Changed? World Scientific, forthcoming.

Kuttner, Kenneth N., \& Shim, Ilhyock. 2012. Taming the Real Estate Beast: The Effects of Monetary and Macroprudential Policies on Housing Crices and Credit. Pages 231-259 of: Heath, Alexandra, Packer, Frank, \& Windsor, Callan (eds), Property Markets and Financial Stability. Sydney: Reserve Bank of Australia.

Lim, Cheng Hoon, Columba, Francesco, Costa, Alejo, Kongsamut, Piyabha, Otani, Akira, Saiyid, Mustafa, Wezel, Torsten, \& Wu, Xiaoyong. 2011. Macroprudential Policy: What Instruments and How to Use Them? Lessons from Country Experiences. Working Paper 11/238. International Monetary Fund.

MacKinlay, A. Craig. 1997. Event Studies in Economics and Finance. Journal of Economic Literature, 35(1), 13-39.

Mishkin, Frederic S. 2011. How should central banks respond to asset price bubbles? The 'lean' versus 'clean' debate after the GFC. Reserve Bank of Australia Bulletin, June, 59-69.

Pesaran, M. Hashem, \& Smith, Ron. 1995. Estimating Long-run Relationships from Dynamic Heterogeneous Panels. Journal of Econometrics, 68(1), 79-113.

Posen, Adam S. 2006. Why Central Banks Should Not Burst Bubbles. International Finance, 9(1), 109-124.

Shim, Ilhyock, Bogdanova, Bilyana, Shek, Jimmy, \& Subelyte, Agne. 2013. Database for Policy Actions on Housing Markets. BIS Quarterly Review, September, 83-95.

Stein, Jeremy C. 2013 (February). Overheating in credit markets: Origins, measurement and policy responses. Speech at the research symposioum on Restoring Household Financial Stability After the Great Recession - Why Household Balance Sheets Matter? at the Federal Reserve Bank of St. Louis.

Svensson, Lars E. O. 2010. Inflation Targeting. Chap. 22 of: Friedman, Benjamin M., \& Woodford, Michael (eds), Handbook of Monetary Economics, vol. 3B. North Holland.

Swamy, P. A. V. B. 1970. Efficient Inference in a Random Coefficient Regression Model. Econometrica, 38(2), 311-323.

Tovar, Camilo, Garcia-Escribano, Mercedes, \& Martin, Mercedes Vera. 2012. Credit Growth and the Effectiveness of Reserve Requirements and Other Macroprudential Instruments in Latin America. Working Paper 12/142. International Monetary Fund.

Vandenbussche, Jérôme, Vogel, Ursula, \& Detragiache, Enrica. 2012. Macroprudential Policies and Housing Prices-A New Database and Empirical Evidence for Central, Eastern and Southeastern Europe. Working Paper 12/303. International Monetary Fund. 
Woodford, Michael. 2012 (April). Inflation Targeting and Financial Stability. Working Paper 17967. National Bureau of Economic Research. 


\section{Data appendix}

Appendix Table 1: Coverage of the policy action dataset

\begin{tabular}{|c|c|c|c|c|c|}
\hline \multirow[t]{3}{*}{ Asia-Pacific } & $\begin{array}{c}\text { Australia } \\
(1996 / 1998)\end{array}$ & $\begin{array}{c}\text { China } \\
(1998 / 1998)\end{array}$ & $\begin{array}{c}\text { Hong Kong SAR } \\
(1988 / 1991)\end{array}$ & $\begin{array}{c}\text { India } \\
(1998 / 1999)\end{array}$ & $\begin{array}{c}\text { Indonesia } \\
(2003 / 2008)\end{array}$ \\
\hline & $\begin{array}{c}\text { Japan } \\
(1999 / 1980)\end{array}$ & $\begin{array}{c}\text { Korea } \\
(2002 / 1988)\end{array}$ & $\begin{array}{c}\text { Malaysia } \\
(1989 / 1989)\end{array}$ & $\begin{array}{l}\text { New Zealand } \\
(1980 / 1980)\end{array}$ & $\begin{array}{c}\text { Philippines } \\
(1980 / 1980)\end{array}$ \\
\hline & $\begin{array}{c}\text { Singapore } \\
(1996 / 1996)\end{array}$ & $\begin{array}{c}\text { Thailand } \\
(1999 / 1999)\end{array}$ & $\begin{array}{c}\text { Chinese Taipei } \\
(2006 / 2000)\end{array}$ & & \\
\hline \multirow[t]{3}{*}{$\begin{array}{l}\text { Central and } \\
\text { eastern Europe }\end{array}$} & $\begin{array}{c}\text { Bulgaria } \\
(1990 / 1990)\end{array}$ & $\begin{array}{c}\text { Croatia } \\
(1997 / 1998)\end{array}$ & $\begin{array}{c}\text { Czech Republic } \\
(1995 / 1990)\end{array}$ & $\begin{array}{c}\text { Estonia } \\
(1993 / 1997)\end{array}$ & $\begin{array}{c}\text { Hungary } \\
(2000 / 2000)\end{array}$ \\
\hline & $\begin{array}{c}\text { Latvia } \\
(1992 / 2000)\end{array}$ & $\begin{array}{c}\text { Lithuania } \\
(1994 / 2000)\end{array}$ & $\begin{array}{c}\text { Poland } \\
(1997 / 2002)\end{array}$ & $\begin{array}{c}\text { Romania } \\
(1998 / 1998)\end{array}$ & $\begin{array}{c}\text { Russia } \\
(1998 / 1992)\end{array}$ \\
\hline & $\begin{array}{c}\text { Serbia } \\
(1999 / 2002)\end{array}$ & $\begin{array}{c}\text { Slovakia } \\
(1993 / 1995)\end{array}$ & $\begin{array}{c}\text { Slovenia } \\
(1996 / 2000)\end{array}$ & $\begin{array}{c}\text { Turkey } \\
(1996 / 2002)\end{array}$ & $\begin{array}{c}\text { Ukraine } \\
(2001 / 2001)\end{array}$ \\
\hline \multirow[t]{2}{*}{ Latin America } & $\begin{array}{c}\text { Argentina } \\
(2000 / 2002)\end{array}$ & $\begin{array}{c}\text { Brazil } \\
(1997 / 1994)\end{array}$ & $\begin{array}{c}\text { Chile } \\
(1991 / 1991)\end{array}$ & $\begin{array}{c}\text { Colombia } \\
(1992 / 1999)\end{array}$ & $\begin{array}{c}\text { Mexico } \\
(1999 / 2011)\end{array}$ \\
\hline & $\begin{array}{c}\text { Peru } \\
(2000 / 2000)\end{array}$ & $\begin{array}{c}\text { Uruguay } \\
(2001 / 2001)\end{array}$ & & & \\
\hline $\begin{array}{l}\text { Middle East } \\
\text { and Africa }\end{array}$ & $\begin{array}{c}\text { Israel } \\
(1999 / 1998)\end{array}$ & $\begin{array}{c}\text { Saudi Arabia } \\
(1998 / 2007)\end{array}$ & $\begin{array}{l}\text { South Africa } \\
(2001 / 1998)\end{array}$ & $\begin{array}{l}\text { United Arab } \\
\text { Emirates } \\
(2001 / 2011)\end{array}$ & \\
\hline North America & $\begin{array}{c}\text { Canada } \\
(1985 / 1981)\end{array}$ & $\begin{array}{c}\text { United States } \\
(1980 / 1980)\end{array}$ & & & \\
\hline \multirow[t]{4}{*}{ Western Europe } & $\begin{array}{c}\text { Austria } \\
(1998 / 1999)\end{array}$ & $\begin{array}{c}\text { Belgium } \\
(1997 / 2000)\end{array}$ & $\begin{array}{c}\text { Denmark } \\
(2003 / 2002)\end{array}$ & $\begin{array}{c}\text { Finland } \\
(1997 / 1987)\end{array}$ & $\begin{array}{c}\text { France } \\
(1997 / 1986)\end{array}$ \\
\hline & $\begin{array}{c}\text { Germany } \\
(1982 / 1982)\end{array}$ & $\begin{array}{c}\text { Greece } \\
(1998 / 1999)\end{array}$ & $\begin{array}{c}\text { Iceland } \\
(1997 / 1999)\end{array}$ & $\begin{array}{c}\text { Ireland } \\
(1999 / 1981)\end{array}$ & $\begin{array}{c}\text { Italy } \\
(1984 / 1981)\end{array}$ \\
\hline & $\begin{array}{c}\text { Luxembourg } \\
(1999 / 1997)\end{array}$ & $\begin{array}{c}\text { Malta } \\
(1998 / 1990)\end{array}$ & $\begin{array}{l}\text { Netherlands } \\
(1998 / 1995)\end{array}$ & $\begin{array}{c}\text { Norway } \\
(1998 / 1980)\end{array}$ & $\begin{array}{c}\text { Portugal } \\
(1996 / 1991)\end{array}$ \\
\hline & $\begin{array}{c}\text { Spain } \\
(1998 / 1999)\end{array}$ & $\begin{array}{c}\text { Sweden } \\
(1997 / 1991)\end{array}$ & $\begin{array}{l}\text { Switzerland } \\
(1980 / 1988)\end{array}$ & $\begin{array}{c}\text { United Kingdom } \\
(1980 / 1981)\end{array}$ & \\
\hline
\end{tabular}

Notes: The first year listed in the brackets for each economy shows the first year official source materials from the monetary, prudential or fiscal authorities were reviewed to identify relevant measures. The second year listed in the brackets shows the first year a relevant policy action is recorded in the dataset for each economy. 
Appendix Table 2: Start and end dates for house price and housing credit data

\begin{tabular}{|c|c|c|c|c|c|}
\hline \multirow[b]{2}{*}{ Country } & \multicolumn{2}{|c|}{ House price } & \multicolumn{2}{|c|}{ Housing credit } & \multirow[b]{2}{*}{ Remarks } \\
\hline & Start & End & Start & End & \\
\hline Argentina & $2003 Q 1$ & 2012Q1 & $2003 Q 1$ & 2012Q2 & Macro instability pre-2003 \\
\hline Austria & $1993 Q 1$ & 2012Q1 & 2003Q1 & 2011Q4 & Extreme price volatility pre-1993 \\
\hline Australia & 1980Q1 & 2012Q1 & 1980Q1 & 2012Q2 & \\
\hline Belgium & 1980Q1 & 2011Q4 & 1980Q1 & 2012Q2 & \\
\hline Bulgaria & $2001 Q 1$ & 2012Q1 & $2001 Q 1$ & 2012Q2 & Macro instability pre-2001 \\
\hline Brazil & 2010Q4 & 2012Q1 & $1997 Q 1$ & 2012Q2 & Extreme credit volatility \\
\hline Canada & 1980Q1 & 2012Q1 & 1980Q1 & 2012Q2 & \\
\hline Switzerland & 1980Q1 & 2012Q1 & 1980Q1 & 2012Q2 & \\
\hline Chile & 1990Q4 & 2007Q4 & 2001Q1 & 2012Q2 & \\
\hline China & $2001 Q 1$ & 2011Q4 & $2001 Q 1$ & 2011Q4 & Extreme price \& credit volatility \\
\hline Colombia & 1988Q1 & $2011 \mathrm{Q} 2$ & 1994Q4 & 2012Q2 & \\
\hline Czech Republic & 1999Q1 & $2010 \mathrm{Q} 4$ & 1997Q1 & $2012 Q 2$ & \\
\hline Germany & 1980Q1 & 2011Q4 & 1980Q4 & 2012Q2 & \\
\hline Denmark & 1980Q1 & 2011Q4 & 2003Q1 & 2012Q2 & \\
\hline Estonia & $2002 Q 1$ & 2012Q1 & $2002 Q 1$ & $2011 Q 4$ & Macro instability pre-2002 \\
\hline Spain & 1987Q1 & 2012Q1 & 1989Q1 & 2012Q1 & \\
\hline Finland & 1980Q1 & 2012Q1 & 1989Q2 & 2012Q2 & \\
\hline France & 1994Q4 & 2011Q4 & 1980Q1 & 2012Q2 & \\
\hline Great Britain & 1980Q1 & 2011Q4 & 1980Q1 & 2012Q1 & \\
\hline Greece & 1993Q4 & 2012Q1 & 1980Q1 & 2012Q2 & \\
\hline Hong Kong SAR & 1993Q1 & 2012Q1 & 1981Q4 & 2012Q2 & \\
\hline Croatia & $1998 Q 1$ & 2010Q4 & 1999Q3 & 2012Q2 & Macro instability pre-1998 \\
\hline Hungary & 2001Q4 & 2012Q1 & $1993 Q 1$ & 2012Q2 & Large spike in credit data \\
\hline Indonesia & $2000 Q 1$ & 2012Q1 & $2000 Q 1$ & 2012Q2 & Macro instability, Asian crisis \\
\hline Ireland & 1980Q1 & 2011Q4 & 1990Q3 & 2012Q2 & \\
\hline Israel & 1994Q1 & 2011Q4 & $2004 Q 1$ & 2011Q1 & Extreme first credit observation \\
\hline India & 2003Q2 & 2012Q1 & 1998Q4 & 2011Q4 & \\
\hline Iceland & 2000Q1 & 2012Q1 & $2009 Q 1$ & 2012Q1 & Credit fell by half during crisis \\
\hline Italy & 1991Q1 & 2011Q4 & 1998Q2 & 2012Q2 & \\
\hline Japan & 1980Q1 & 2011Q4 & 1980Q1 & 2012Q1 & \\
\hline Korea & 1986Q1 & 2012Q1 & 1996Q1 & 2012Q2 & \\
\hline Lithuania & 1998Q4 & 2011Q4 & 2004Q1 & 2012Q2 & \\
\hline Luxembourg & 1980Q1 & 2011Q4 & 1999Q1 & 2012Q2 & \\
\hline Latvia & 2006Q1 & 2011Q4 & 2003Q3 & 2012Q2 & \\
\hline Malta & 2000Q1 & 2011Q4 & 1996Q1 & 2012Q2 & \\
\hline Mexico & 2005Q1 & 2012Q1 & 1996Q4 & 2012Q2 & \\
\hline Malaysia & 1999Q1 & $2011 \mathrm{Q} 4$ & 1996Q4 & $2012 \mathrm{Q} 2$ & \\
\hline Netherlands & $1985 Q 1$ & 2012Q1 & 1990Q4 & 2012Q2 & Extreme price volatility pre-1985 \\
\hline Norway & 1991Q1 & 2012Q1 & 1991Q3 & 2012Q2 & \\
\hline New Zealand & 1980Q1 & $2011 Q 4$ & 1998Q2 & 2012Q2 & \\
\hline
\end{tabular}

Continued on next page 


\begin{tabular}{|c|c|c|c|c|c|}
\hline \multirow[b]{2}{*}{ Country } & \multicolumn{2}{|c|}{ House price } & \multicolumn{2}{|c|}{ Housing credit } & \multirow[b]{2}{*}{ Remarks } \\
\hline & Start & End & Start & End & \\
\hline Peru & $2002 Q 1$ & 2012Q1 & $2002 Q 1$ & 2012Q2 & Macro instability pre-2002 \\
\hline Philippines & 1981Q1 & 2011Q4 & $2001 Q 3$ & 2012Q1 & Extreme first two credit observations \\
\hline Poland & 2002Q4 & 2012Q1 & 1996Q4 & 2012Q2 & \\
\hline Portugal & 1988Q1 & 2012Q1 & 1980Q1 & 2012Q2 & \\
\hline Romania & 2005Q4 & 2011Q4 & 2007Q1 & 2012Q2 & \\
\hline Serbia & 2003Q2 & 2011Q4 & 2008Q2 & 2012Q2 & \\
\hline Russia & 2001Q1 & 2011Q4 & 2004Q2 & 2012Q2 & \\
\hline Sweden & $1993 Q 1$ & 2012Q1 & 2001Q4 & 2012Q2 & \\
\hline Singapore & 1980Q1 & 2012Q1 & 1991Q1 & 2012Q2 & \\
\hline Slovenia & 2003Q1 & 2011Q4 & $2005 Q 2$ & 2012Q2 & Extreme first two credit observations \\
\hline Slovakia & 2005Q1 & 2012Q1 & 2006Q1 & 2012Q2 & \\
\hline Thailand & $1999 Q 1$ & 2011Q2 & $1999 Q 1$ & 2012Q2 & Macro instability, Asian crisis \\
\hline Turkey & 2007Q2 & 2011Q4 & $2007 Q 1$ & 2012Q2 & Large spike in credit data \\
\hline Chinese Taipei & 1991Q3 & 2011Q3 & 1988Q3 & 2012Q2 & \\
\hline Ukraine & 2000Q2 & 2012Q1 & 2006Q1 & 2012Q2 & \\
\hline United States & 1980Q1 & 2012Q1 & 1980Q1 & 2012Q1 & \\
\hline South Africa & 1980Q1 & 2012Q1 & 1980Q1 & 2012Q2 & \\
\hline
\end{tabular}

Notes: Italicized entries are those for which the starting date was moved up to exclude extreme or highly volatile observations. The shaded grey entries are dropped from the regressions because of insufficient data. 